\section{Bell Pepper Fruit Yield and Quality as Influenced by Solar Radiation-based Irrigation and Container Media in a Passively Ventilated Greenhouse}

\author{
Elio Jovicich ${ }^{3}$ and Daniel J. Cantliffe ${ }^{1}$ \\ Horticultural Sciences Department, University of Florida, 1143 Fifield Hall, \\ P.O. Box 110690, Gainesville, FL 32611-0690
}

\author{
Peter J. Stoffella ${ }^{2}$ \\ Indian River Research and Education Center, University of Florida, \\ 2199 South Rock Road, Ft. Pierce, FL 34945-3138
}

\author{
Dorota Z. Haman' \\ Agricultural \& Biological Engineering Department, University of Florida, \\ Frazier Rogers Hall, P.O. Box 110570, Gainesville, FL 32611-0570
}

Additional index words. Capsicum annuum, blossom-end rot, fruit cracking, irrigation frequency, nutrient solution, water use efficiency

\begin{abstract}
Frequent fertigation of soilless-grown bell pepper (Capsicum annuum L.) can increase fruit production, but development of fruit disorders may offset the increase in yield of first-quality (blemish-free) fruit in greenhouses with minimal environmental control. Fruit yield and quality were studied as affected by water volumes and nutrient concentration levels, delivered with irrigation events initiated after determined cumulative solar radiation levels, in 'HA3378' bell pepper from October to May in northcentral Florida. Irrigation events occurred after solar radiation integral levels (SRI; \pm SD) $1.7 \pm 0.42,3.7 \pm 0.42,5.7 \pm 0.42,7.7 \pm 0.42$, and $9.7 \pm 0.42 \mathrm{~kW} \cdot \mathrm{min}^{-1} \cdot \mathrm{m}^{-2}$, which led to mean number of daily irrigation events of $61 \pm 31,26 \pm 12,17 \pm 8,12 \pm 5$, and $10 \pm 4$ respectively. In peat mix, perlite, and pine bark media, volume per irrigation event and concentration levels of the nutrient solution were, in the first experiment, $74 \mathrm{~mL}$ standard (74-s), and in a second concurrent experiment, $74 \mathrm{~mL}$ half-standard (74-1/2s) or 3$) 37 \mathrm{~mL}$ standard (37-s). In both studies, combined marketable fruit yields of first quality and second quality (minor cracking patterns and yellow spots) increased linearly with decreasing SRI (increased events per day). First-quality fruit weight with 74-s was unaffected by media and, in a quadratic response to SRI, reached $5.4 \mathrm{~kg} \cdot \mathrm{m}^{-2}$ at 5.7 $\mathrm{kW} \cdot \mathrm{min}^{-1} \cdot \mathrm{m}^{-2}$. First-quality weight with $74-1 / 2 \mathrm{~s}$ and $37-\mathrm{s}$ did not differ. Weight was unaffected by SRI in peat mix and perlite, and a quadratic response was recorded in pine bark, with yields of $\leq 3.6 \mathrm{~kg} \cdot \mathrm{m}^{-2}$. Fruit cracking incidence decreased with increased SRI, and was generally greater in pine bark. Incidence of yellow spots doubled with $74-1 / 2 \mathrm{~s}$ compared with $37-\mathrm{s}$, and decreased linearly with increased SRI; the disorder was minor with 74-s. Compared with $37-\mathrm{s}, 74-1 / 2$ s decreased fruit with blossom-end rot by $14 \%$, increased marketable fruit weight by $10 \%$ in media with the lowest water-holding capacity (perlite, pine bark), and increased nutrient use efficiency. With any media used, the SRI set point of $5.7 \mathrm{~kW} \cdot \mathrm{min}^{-1} \cdot \mathrm{m}^{-2}$ (daily mean of 17 irrigation events) and $74 \mathrm{~mL}$, at standard nutrient concentration levels, appeared to produce greater blemish-free fruit yield than delivering $37 \mathrm{~mL} /$ event or half-concentrated $74 \mathrm{~mL} /$ event within the range of SRI means of 1.7 to $9.7 \mathrm{~kW} \cdot \mathrm{min}^{-1} \cdot \mathrm{m}^{-2}(61-10$ irrigation events/day). Disorder-tolerant pepper cultivars, better temperature control, and August plantings are additional suggestions for irrigation management to increase first-quality fruit yield.
\end{abstract}

\footnotetext{
Received for publication 22 Oct. 2006. Accepted for publication 10 Jan. 2007.

We are very thankful for the help provided by Larry W. Miller from the Agricultural and Biological Engineering Department, by Dr. Camilo Cornejo from the Soil and Water Science Department, University of Florida, and by Javier J. Flores. ${ }^{1}$ Professor and chairman.

${ }^{2}$ Professor and Associate Center director.

${ }^{3}$ To whom reprint requests should be addressed; e-mail jovicich@ufl.edu
}

The production area of colored bell pepper (Capsicum annuum L.) is the largest among vegetable crops grown in greenhouses in Florida (Jovicich et al., 2005), a peninsula with a mild winter and subtropical climate. Pepper plants grown in containers with soilless media and irrigated with nutrient solution get sufficient protection in high-roof, passively ventilated greenhouses (with or without heaters used occasionally). Market- able yields range from 6 to $15 \mathrm{~kg} \cdot \mathrm{m}^{-2}$, and are primarily dependent on the level of technology used for climate control and duration of the harvest period (Jovicich et al., 2004a, 2005). Grown in simple and low-cost production systems, with low-to-medium capability for controlling environmental conditions, pepper plants can experience periods of extreme high or low air temperature, radiation, and air relative humidity (Jovicich et al., 2004a, b; Rilsky et al., 1994). Plants can be productive despite temporary suboptimal environments, but the yield of high-quality colored fruit can be reduced as a result of physiological disorders such as cracking on fruit walls (russet and radial scars), yellow spots, and necrosis on the blossom end of the fruit (Aloni et al., 1994, 1998, 1999; Marcelis and Ho, 1999; Nuez et al., 1996; Rilsky et al., 1994). Fruit with blossom-end rot are unmarketable, whereas fruit with cracking and color spots may be sold as a lower quality fruit, or may be unmarketable, depending on the severity of the injury, aesthetic appearance, and market demand. These fruit disorders result from interactions among temperature, humidity, radiation, and water and nutrient status in the plant (Portree, 1996; Rilsky et al., 1994). Irrigation and fertilization can be managed to minimize the occurrence of fruit disorders and to maximize the marketability of the produce.

Yield and quality of fruit in containerized pepper and tomato (Lycopersicum esculentum Mill.) plants are affected in similar ways by frequency and volume of irrigation events, and by concentration of nutrients in the delivered solution (Dorais et al., 2001; Silber et al., 2005 b). Changes in media moisture conditions, nutrient levels, and electrical conductivity (EC) in the media can reduce fruit quality in these crops (Aloni et al., 1999; de Kreij et al., 1992; Dorais et al., 2001; Ehret et al., 1993). With fruit and leafy vegetables grown under frequent irrigation events, and in warm environments, nutrient solution concentration levels can be set lower than in cool environments if plants receive sufficient amounts of water (Adams, 2002; Silber et al., 2003, 2005a; Sonnenveld, 2002). For irrigation management purposes in different soilless media it is important to determine whether high frequency of irrigation with a solution with low nutrient concentration levels leads to fruit yield and quality similar to that obtained with a lower irrigation frequency and higher nutrient concentration levels in the solution.

Solar radiation can be used as a parameter to schedule irrigation events in soillessgrown plants, with adjustments of radiation set points (which initiate irrigation events) made based on plant growth stage and fruit load, solar radiation, temperature, or irrigation drainage fraction (Kläring, 2001; Portree, 1996; Shelford et al., 2004; Shröder and Lieth, 2002). The principle of this irrigation control method is based on the association among plant water uptake, nutrient uptake, and transpiration rate, which is closely related to solar radiation (Adams, 1992; Morris et al., 1957; Sonnenveld, 2002). When 
water and fertilizer rates are evaluated for effects on fruit yield, it is also important to determine water and nutrient use efficiencies, because an increase in water delivered and fertilizer applied without a corresponding yield benefit wastes resources, increases production costs, and leads to environmental pollution when drained nutrient solution is not contained or recycled.

Soilless media commonly used in Florida's greenhouse vegetable industry are perlite, pine bark, and commercial peatmoss-based mixtures. These media have adequate aeration porosity and water-holding capacity (Burés, 1997; Pokorny, 1987; Raviv et al., 2002). Comparable yields of vegetables can be obtained with media with different physical properties, providing media are irrigated sufficiently with water and nutrients for plants (Raviv et al., 2002). Media with low water-holding capacity require more frequent irrigation and may need greater volumes per irrigation event to be delivered, than media with greater water-holding capacity (Raviv et al., 2002).

The objective of this study was to investigate effects of solar radiation-based irrigation frequency and volume of nutrient solution delivered at each irrigation event on fruit yield and quality of bell pepper plants grown in several types of soilless media in a passively ventilated greenhouse.

\section{Materials and Methods}

Two greenhouse experiments were conducted concurrently to evaluate the effects of five solar radiation-based irrigation frequency schedules, two volumes of nutrient solutions per irrigation event, and three growing media on fruit yield and quality of 'HA3378' bell pepper (Hazera Seeds Ltd., Grover Beach, Calif.; Table 1). This commercial cultivar was identified in other studies as being sensitive to fruit disorders such as fruit cracking, yellow spots, and blossomend rot (Jovicich et al., 2004b; Shaw and Cantliffe, 2002). Experiments were conducted in a single bay (width $\times$ length $\times$ height, $8 \times 32 \times 9 \mathrm{~m}$; roof with two polyethylene film layers, 200 and $150 \mu \mathrm{m}$ in thickness) of a seven-bay passively ventilated greenhouse (Top Greenhouses Ltd., Rosh Ha'ayin, Israel) oriented north-south, and located at the Horticultural Science Protected Agriculture Center, University of Florida, in Gainesville, Fla. (lat., $29^{\circ} 39^{\prime} \mathrm{N}$; long., $\left.82^{\circ} 19^{\prime} \mathrm{W}\right)$.

Container media and plant arrangement. Pepper seedlings were grown on a $70 \%$ peatmoss: $30 \%$ vermiculite $(\mathrm{v} / \mathrm{v})$ substrate mix (Promix 0463, Premier, Quebec) in 128cell (top width $\times$ top length $\times$ height, $3.5 \times$ $3.5 \times 6.5 \mathrm{~cm} ; 35 \mathrm{~mL} /$ cell) polystyrene transplant flats (Speedling, Sun City, Fla.). Seedlings were fertigated (every 1 or $2 \mathrm{~d}$ ), after the first leaves unfolded, using a solution with nutrient levels of $\mathrm{NO}_{3}{ }^{-} \mathrm{N}, 70 \mathrm{mg} \cdot \mathrm{L}^{-1} ; \mathrm{P}$, $50 \mathrm{mg} \cdot \mathrm{L}^{-1} ; \mathrm{K}, 100 \mathrm{mg} \cdot \mathrm{L}^{-1} ; \mathrm{Ca}, 90 \mathrm{mg} \cdot \mathrm{L}^{-1}$; $\mathrm{Mg}, 40 \mathrm{mg} \cdot \mathrm{L}^{-1} ; \mathrm{S}, 56 \mathrm{mg} \cdot \mathrm{L}^{-1} ; \mathrm{Fe}, 2.8 \mathrm{mg} \cdot \mathrm{L}^{-1}$; $\mathrm{Cu}, 0.2 \mathrm{mg} \cdot \mathrm{L}^{-1} ; \mathrm{Mn}, 0.8 \mathrm{mg} \cdot \mathrm{L}^{-1} ; \mathrm{Zn}$, $0.3 \mathrm{mg} \cdot \mathrm{L}^{-1} ; \mathrm{B}, 0.7 \mathrm{mg} \cdot \mathrm{L}^{-1}$; and Mo, $0.06 \mathrm{mg} \cdot \mathrm{L}^{-1}$.
Table 1. Solar radiation-based irrigation frequency, volume per irrigation event, and nutrient concentration treatments used to irrigate greenhouse-grown bell pepper plants in $11.3-\mathrm{dm}^{3}$ containers with peat mix, perlite, or pine bark in two concurrent experiments with cropping seasons from 10 Oct. 1999 (transplanting) to 4 May 2000 (seventh fruit harvest).

\begin{tabular}{cccc}
\hline & $\begin{array}{c}\text { Irrigation } \\
\text { solar } \\
\text { radiation } \\
\text { integral }^{2} \\
\left(\mathrm{~kW} \cdot \mathrm{min}^{-1} \cdot \mathrm{m}^{-2}\right)\end{array}$ & $\begin{array}{c}\text { Volume per } \\
\text { irrigation } \\
\text { event }^{\mathrm{y}} \\
(\mathrm{mL} / \mathrm{event})\end{array}$ & $\begin{array}{c}\text { Solution } \\
\text { nutrient } \\
\text { concn }^{\mathrm{x}}\end{array}$ \\
\hline 1 & 1.7 & 74 & $\mathrm{~s}$ \\
& 3.7 & 74 & $\mathrm{~s}$ \\
& 5.7 & 74 & $\mathrm{~s}$ \\
& 7.7 & 74 & $\mathrm{~s}$ \\
& 9.7 & 74 & $\mathrm{~s}$ \\
& 1.7 & 74 & $1 / 2 \mathrm{~s}$ \\
& 3.7 & 37 & $\mathrm{~s}$ \\
& & 74 & $1 / 2 \mathrm{~s}$ \\
& 5.7 & 37 & $\mathrm{~s}$ \\
& & 74 & $1 / 2 \mathrm{~s}$ \\
& 7.7 & 37 & $\mathrm{~s}$ \\
& & 74 & $1 / 2 \mathrm{~s}$ \\
& 9.7 & 74 & $\mathrm{~s}$ \\
& & 37 & $\mathrm{~s}$ \\
\hline
\end{tabular}

${ }^{\mathrm{z}}$ Mean set-point values of solar radiation input in an irrigation controller initiated irrigation events and created five irrigation schedules during a 206-day crop period. See "Materials and Methods" for details regarding treatments.

${ }^{\mathrm{y}}$ Per plant in 1-min irrigation events.

${ }^{\mathrm{x}}$ Standard (s) or half-standard ( $\left.1 / 2 \mathrm{~s}\right)$ nutrient concentration levels in the irrigation solution. Concentration levels for individual nutrients are presented in Table 2 .

Seedlings ( 5 weeks old) were transplanted on 10 Oct. 1999 into $11.3-\mathrm{dm}^{3}$ black polyethylene nursery pots (diameter, $25 \mathrm{~cm}$; height, $30 \mathrm{~cm}$; model A-30, Lerio Corp., Kissimmee, Fla.) containing soilless media: 1) a commercial peat mix made of $60 \%$ peatmoss, $20 \%$ vermiculite, and $20 \%$ perlite (v/v/v; Speedling, Bushnell, Fla.); 2) only "horticultural-grade" perlite (Airlite Processing Corporation of Florida, Vero Beach, Fla.); or 3) only pine bark (from Pinus elliottii, particle size less than $6.3 \mathrm{~cm}^{2}$; Elixon Wood Products, Starke, Fla.). Media waterholding capacity $(\mathrm{v} / \mathrm{v})$, determined as water content in container medium after drainage from saturation (Raviv et al., 2002), was $59.7 \%$ for peat mix, $31.6 \%$ for perlite, and $28.8 \%$ for pine bark for a substrate depth of $25 \mathrm{~cm}$. Plant spacing within the rows was $25 \mathrm{~cm}$ and row spacing was $1.33 \mathrm{~m}$ (there were three plants $/ \mathrm{m}^{2}$ ). Plants were pruned to form two main stems, which were vertically trellised to a "V" canopy system (Jovicich et al., 2004b). Bumblebees (Bombus impatiens Cresson; Koppert Biological Systems, Ann Arbor, Mich.) were used as pollinators with $\approx 1$ bee $/ 100$ plants.

Volume and nutrients delivered at each irrigation event. Each plant was irrigated with a complete nutrient solution for 1-min events with one or two pressure-compensated drip emitters connected to stakes (average flow/emitter, $37 \mathrm{~mL} \cdot \mathrm{min}^{-1}$ at $139 \mathrm{kPa}$; Neta- fim, Altamonte Springs, Fla.). Two fertilizer proportional injectors (model DI 16-11; Dosatron International Inc., Clearwater, Fla.) placed in a series were used to pump concentrated stock solutions into the irrigation water (dilution rate, 1:100; v/v). Nutrient levels for peppers were adapted from those formulated for hydroponic greenhousegrown tomatoes (Hochmuth, 1991; Jovicich, 2001) and, in this study, are referred to as standard nutrient concentration levels (Table 2). The drainage of solution from the plant containers was collected and delivered to a nearby pasture.

In Expt. 1, each plant received 74 $\mathrm{mL} /$ event from two emitters that delivered standard nutrient concentration levels (designated 74-s) that had a $\mathrm{pH}$ range from 5.5 and 6.5 , and EC that ranged from 1.4 to $2.5 \mathrm{mS} \cdot \mathrm{cm}^{-1}$, depending on plant growth stage (Table 2). In Expt. 2, 'HA3378' pepper plants were irrigated with two volumes: 1) 74 $\mathrm{mL} /$ event, but at half the standard nutrient concentration levels (designated $74-1 / 2 \mathrm{~s}$ ), or 2 ) $37 \mathrm{~mL} /$ event with standard nutrient concentration levels (designated 37-s). The volume for $74-1 / 2 \mathrm{~s}$ ( $\mathrm{pH}$ range, 5.5-6.5; EC range, 1.4$1.7 \mathrm{mS} \cdot \mathrm{cm}^{-1}$ ) was achieved by using two attached stake drippers in each plant, one emitter connected to an irrigation pipe that delivered nutrient solution at standard concentration (Table 2) and the other connected to a pipe that delivered water. The volume for 37-s was delivered using one emitter/plant. Plants in Expt. 2 were grown with the same five irrigation schedules and three media types as in Expt. 1 (Table 1).

Control and schedule of irrigation events. A pyranometer (LI200X; LI-COR, Inc., Lincoln, Nebr.) was placed inside the greenhouse at a height of $2 \mathrm{~m}$ and was connected to a data-logger processor (CR10X; Campbell Scientific, Logan, Utah) to measure total solar radiation $\left(\mathrm{W} \cdot \mathrm{m}^{-2}\right)$ at 1 -min intervals. The algorithm in the processor calculated and summed radiation integrals, and commanded the opening of irrigation valves whenever cumulative radiation measured inside the greenhouse reached preset values of solar radiation integrals (SRIs, measured in units of kilowatts per min per square meter, which is equal to $0.0166 \mathrm{~kW} \cdot \mathrm{s}^{-1} \cdot \mathrm{m}^{-2}$ or $0.060 \mathrm{MJ} \cdot \mathrm{m}^{-2}$ ). Small SRI values input in the controller created short periods between irrigation events (especially at noon and early afternoon hours on clear days) and led to more irrigation events per day than using large SRI set points. The data logger registered solar radiation and time when irrigation events occurred.

After transplanting, all plants from both experiments were subject to a crop establishment period of $38 \mathrm{~d}$, during which all treatments shared an irrigation schedule with a mean \pm SD of $11 \pm 3$ irrigation events/day ( $37 \mathrm{~mL} /$ event of a solution with standard nutrient concentration levels) from a preset SRI of $8 \mathrm{~kW} \cdot \mathrm{min}^{-1} \cdot \mathrm{m}^{-2}$. On 17 Nov., $39 \mathrm{~d}$ after transplanting (DAT), treatment volumes of 74-s, $74-\frac{1}{2} \mathrm{~s}$, or $37-\mathrm{s}$ began to be delivered to plants with irrigation schedules with SRI levels of 3 , 
Table 2. Target concentrations of nutrients in the solution with standard nutrient concentration levels delivered to plants irrigated with $74 \mathrm{~mL} /$ event in Expt. 1 and with $37 \mathrm{~mL} / \mathrm{event}$ in Expt. 2, in greenhouse-grown bell peppers from 10 Oct. 1999 to 4 May 2000.

\begin{tabular}{|c|c|c|c|c|c|}
\hline \multirow[b]{2}{*}{ Nutrient $^{\mathrm{z}}$} & \multirow{2}{*}{$\begin{array}{l}\text { Transplant and } \\
\text { vegetative } \\
\text { growth } 10-31 \\
\text { Oct. }(0-21 \text { DAT }) \\
\left(\mathrm{mg} \cdot \mathrm{L}^{-1}\right)\end{array}$} & \multicolumn{2}{|c|}{$\begin{array}{l}\text { Vegetative growth } \\
\text { until fruit set }\end{array}$} & \multirow[b]{2}{*}{$\begin{array}{c}\text { Fruit set } 2-16 \text { Dec. } \\
\qquad(62-76 \mathrm{DAT}) \\
\left(\mathrm{mg} \cdot \mathrm{L}^{-1}\right)\end{array}$} & \multirow{2}{*}{$\begin{array}{c}\text { Fruit set to } \\
\text { seventh harvest } \\
17 \text { Dec. } 4 \text { May } \\
(77-206 \text { DAT }) \\
\left(\mathrm{mg} \cdot \mathrm{L}^{-1}\right)\end{array}$} \\
\hline & & $\begin{array}{c}1-17 \text { Nov. } \\
(22-38 \text { DAT }) \\
\left(\mathrm{mg} \cdot \mathrm{L}^{-1}\right)\end{array}$ & $\begin{array}{c}18 \text { Nov. }-1 \text { Dec. } \\
(39-61 \text { DAT }) \\
\left(\mathrm{mg} \cdot \mathrm{L}^{-1}\right)\end{array}$ & & \\
\hline$\overline{\mathrm{N}^{\mathrm{x}}}$ & 70 & 80 & 100 & 120 & 156 \\
\hline $\mathrm{P}$ & 50 & 50 & 50 & 50 & 50 \\
\hline $\mathrm{K}$ & 119 & 119 & 148 & 148 & 203 \\
\hline $\mathrm{Ca}$ & 111 & 127 & 143 & 174 & 190 \\
\hline $\mathrm{Mg}$ & 40 & 40 & 40 & 48 & 48 \\
\hline $\mathrm{S}$ & 56 & 56 & 56 & 66 & 66 \\
\hline
\end{tabular}

${ }^{\mathrm{z}}$ Supplied with every drip irrigation event. Concentration levels of micronutrients $\left(\mathrm{mg} \cdot \mathrm{L}^{-1}\right)$ were constant throughout the season: $\mathrm{Fe}, 2.8 ; \mathrm{Cu}, 0.2 ; \mathrm{Mg}, 0.8 ; \mathrm{Zn}, 0.3 ; \mathrm{B}, 0.7$; and $\mathrm{Mo}, 0.06$.

${ }^{\mathrm{y}}$ Crop stages and periods of time during which plants were irrigated with the same nutrient concentration levels.

${ }^{\mathrm{x}}$ All-nitrate source.

Plants irrigated with $74 \mathrm{~mL} /$ event in Expt. 2 received a solution with half the nutrient concentration levels indicated in this table.

DAT, days after transplanting.

$5,7,9$, or $11 \mathrm{~kW} \cdot \mathrm{min}^{-1} \cdot \mathrm{m}^{-2}$. It was not the intent of the study to keep the SRI set points constant throughout the crop season, because these are normally adjusted several times to lower levels as plants grow, and light and temperature increase during the season (Shelford et al., 2004). From 39 to 206 DAT, all five SRI levels were equally decreased by the following amounts: $1 \mathrm{~kW} \cdot \mathrm{min}^{-1} \cdot \mathrm{m}^{-2}$ on 29 Nov. $1999,0.9 \mathrm{~kW} \cdot \mathrm{min}^{-1} \cdot \mathrm{m}^{-2}$ on 22 Dec. $1999,0.4 \mathrm{~kW} \cdot \mathrm{min}^{-1} \cdot \mathrm{m}^{-2}$ on 9 Jan. 2000 , and $0 . \mathrm{kW} \cdot \mathrm{min}^{-1} \cdot \mathrm{m}^{-2}$ on $26 \mathrm{Feb} .2000$. At the time these adjustments were implemented, daily drainage from containers with any media irrigated at the middle level of SRI treatment (37-s) was within the range of $10 \%$ to $30 \%$ of the volume irrigated on the previous day.

Fruit harvest and classification. Red fruits were harvested on 5 Feb., 11 Feb., 18 Feb., 2 Mar., 22 Mar., 13 Apr., and 4 May $(118,124,131,144,164,186$, and 206 DAT respectively). Marketable fruit were weighed, counted, and graded by size following a diameter scale used for imported greenhouse-grown bell peppers: extra-large (diameter $>84.0 \mathrm{~mm})$, large $(76.0-83.9 \mathrm{~mm})$, medium (64.0-75.9 mm), and small (56.0$63.9 \mathrm{~mm}$ ) (Jovicich et al., 2005). Within the marketable fruit category, fruit with any visible scar from radial or russet cracking, or with yellow spots, were classified as second-quality fruit, whereas those without these blemishes were classified as first quality. Unmarketable fruit included fruit with blossom-end rot and fruit with a diameter smaller than $55.9 \mathrm{~mm}$.

Crop water and nutrient use efficiency. Total amounts of water and macro nutrients $\mathrm{N}, \mathrm{P}, \mathrm{K}, \mathrm{Ca}$, and $\mathrm{Mg}$ applied to each treatment were calculated from the number of irrigation events per day, volume of water delivered to the plants, and target nutrient concentration levels. The crop water and nutrient use efficiencies for marketable yield were calculated as the total amount of water delivered (in liters per square meter) or nutrient applied (in grams per square meter) divided by the total marketable fruit (in kilograms per row cover (density, $14.2 \mathrm{~g} \cdot \mathrm{m}^{-2}$; Suntex CP, Sarasota, Fla.) and, later in January, by operating propane burners on four nights.

From 10 Oct. 1999 to 4 May 2000, air temperature means $( \pm \mathrm{SD})$ inside the greenhouse were $20 \pm 3.4^{\circ} \mathrm{C}$ for the daily average, $12 \pm 4.4{ }^{\circ} \mathrm{C}$ for the daily minimum, and $32 \pm$ $4.3{ }^{\circ} \mathrm{C}$ for the daily maximum (Fig. 1B). Lowest outside air temperatures (as low as $-5{ }^{\circ} \mathrm{C}$ ) were recorded in December and January, and there were $19 \mathrm{~d}$ with frost. Minimum air temperatures inside the greenhouse were within the ranges of 2 to $4{ }^{\circ} \mathrm{C}$ on $12 \mathrm{~d}, 5$ to $10^{\circ} \mathrm{C}$ on $25 \mathrm{~d}$, and 11 to $15^{\circ} \mathrm{C}$ on $93 \mathrm{~d}$. Daily integrated solar radiation increased after January (Fig. 1A). Maximum air temperatures inside the greenhouse were within the ranges of 20 to $25^{\circ} \mathrm{C}$ on $12 \mathrm{~d}, 26$ to $30{ }^{\circ} \mathrm{C}$ on $35 \mathrm{~d}, 31$ to $35^{\circ} \mathrm{C}$ on $101 \mathrm{~d}$, and 36 to $42{ }^{\circ} \mathrm{C}$ on $17 \mathrm{~d}$.

A reference evapotranspiration $\left(\mathrm{ET}_{0}\right)$ was calculated for climate data (daily solar radiation, temperature, and estimated relative humidity) inside the greenhouse using the Penman-Monteith method (Allen et al., 1998). Cumulative volumes of water from irrigation treatments were expressed as a ratio of the cumulative $\mathrm{ET}_{0}$ inside the greenhouse.

Experimental designs and data analyses. Expt. 1 (all plants irrigated with volume 74-s) was arranged as a randomized block design with four plants/experimental unit. The five solar radiation-based irrigation schedule levels (SRI levels 1.7, 3.7, 5.7, 7.7, and $9.7 \mathrm{~kW} \cdot \mathrm{min}^{-1} \cdot \mathrm{m}^{-2}$ ) constituted the five blocks, whereas four replications of the three container media types (peat mix, perlite, and pine bark) were randomized within irrigation schedule treatments. Analyses of variance (ANOVAs) were performed on measured variables (SAS Institute, 1999). Expt. 2 was arranged as a split-split plot replicated in three blocks. The main plot was solar radiation-based irrigation schedule, the subplot was the volume at each irrigation event (74-1/2s and 37-s), and the subsubplot was
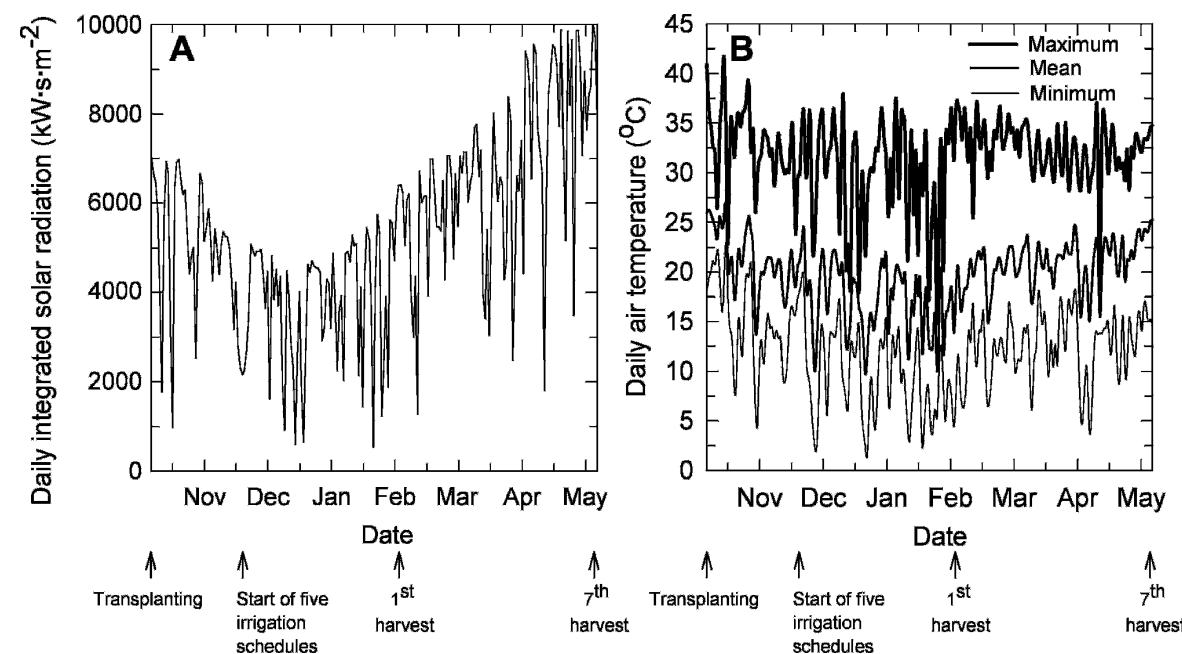

Fig. 1. (A, B) Daily integrated solar radiation measured over bell pepper plant canopies (A) and air temperatures $(\mathbf{B})$ inside a passively ventilated greenhouse with minimum use of fuel for heating, during a 206-d crop period from 10 Oct. 1999 to 4 May 2000. 
the container media type. Each experimental unit consisted of four plants. Analysis of variance was performed using PROC GLM in SAS (SAS Institute, Cary, N.C.) with separate calculations for appropriate error terms for the $\mathrm{F}$ tests of interactions (Cochran and Cox, 1957) and Satterthwaite's approximation formula for df (Montgomery, 1997). In both experiments, SRI was treated as a continuous variable, and main effects and effects in significant interactions involving SRI were partitioned into linear, quadratic, and cubic orthogonal contrasts. Differences between means were compared using Duncan's multiple range test $(\alpha=0.05)$. Values expressed as percentages were arcsin transformed before conducting ANOVA; actual means are presented in tables or figures.

\section{Results}

Irrigation frequency, and volumes of water and amounts of nutrients delivered. For the 206-d crop, the response of all number of irrigation events per day to the preset SRI levels was cubic (Fig. 2). Overall means \pm SD for daily number of irrigation events in each irrigation schedule were $61 \pm$ $31,26 \pm 12,17 \pm 8,12 \pm 5$, and $10 \pm 4$ for the mean SRI levels of 1.7, 3.7, 5.7, 7.7, and $9.7 \mathrm{~kW} \cdot \mathrm{min}^{-1} \cdot \mathrm{m}^{-2}$ (all \pm 0.42 ) respectively. Because of the distribution of solar radiation throughout the day, numbers of irrigation

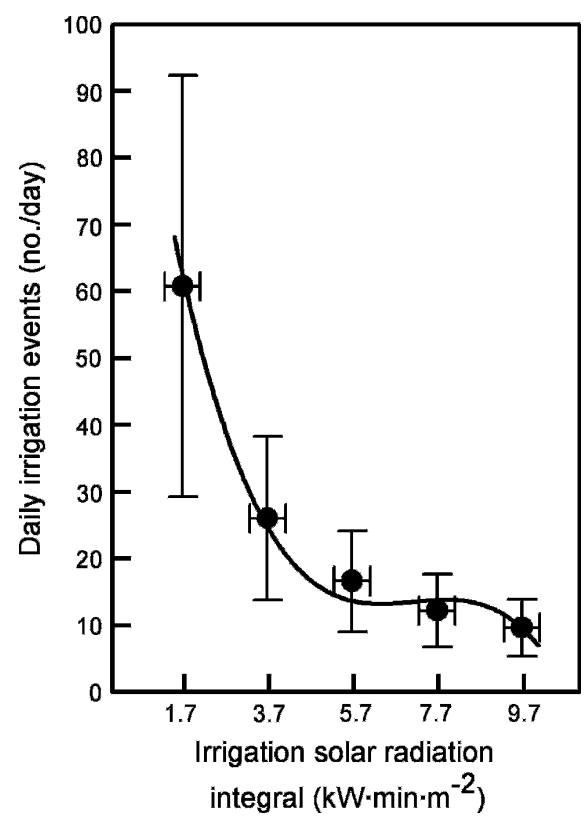

Fig. 2. Daily number of irrigation events in response to solar radiation integrals used to initiate irrigation events in greenhouse-grown bell peppers in concurrent Expts. 1 and $2(\mathrm{y}=$ $125.04-48.26 \mathrm{x}+6.87 \mathrm{x}^{2}-0.32 \mathrm{x}^{3} ; R^{2}=0.70 ;$ $P<0.001)$. Crop period was $206 \mathrm{~d}$, from 10 Oct. to 4 May 2000. Mean solar radiation integral values $( \pm \mathrm{SD})$ of the five irrigation schedule treatments imposed to plants were $1.7,3.7,5.7,7.7$, and $9.7 \mathrm{~kW} \cdot \mathrm{min}^{-1} \cdot \mathrm{m}^{-2}$, and mean number of irrigation events per day $( \pm \mathrm{SD})$ were $61,26,17,12$, and 10 events/day. events from the five schedules were not equally spaced (Fig. 2). Treatments resulted in total water volumes that ranged from 195 to $2469 \mathrm{~L} \cdot \mathrm{m}^{-2}$ and total amount of nutrients that differed up to 12.3 times (Table 3 ). On the seventh harvest, cumulative $\mathrm{ET}_{0}$ was $263 \mathrm{~L} \cdot \mathrm{m}^{-2}$ and mean daily $\mathrm{ET}_{0}$ was $1.2 \pm$ $0.4 \mathrm{~L} \cdot \mathrm{m}^{-2}$. At that moment, total delivered water with SRI levels of 1.7, 3.7, 5.7, 7.7, and $9.7 \mathrm{~kW} \cdot \mathrm{min}^{-1} \cdot \mathrm{m}^{-2}$ (Table 3 ) corresponded to ratios between cumulative irrigation volume and $\mathrm{ET}_{0}$ of 9.4, 4.0, 2.6, 1.9, and 1.5 with $74 \mathrm{~mL} /$ event treatments respectively, and 4.7 , $2.0,1.3,0.9$, and 0.7 with $37 \mathrm{~mL} /$ event treatments respectively (Fig. 3). Estimation of daily irrigation volume from SRI schedules with linear equations (not presented) had $r^{2}$ values in the range of 0.57 to 0.61 when using daily $\mathrm{ET}_{0}$ as an independent variable.

Fruit yield and quality, and water and nutrient use efficiency: Expt. 1. With 74-s, total marketable yield (combined weight of first- and second-quality fruit averaged across media) increased linearly with decreased SRI levels, but weight of first-quality fruit responded quadratically, with $5.4 \mathrm{~kg} \cdot \mathrm{m}^{-2}$ being produced at SRI $5.7 \mathrm{~kW} \cdot \mathrm{min}^{-1} \cdot \mathrm{m}^{-2}$ (Fig. 4). The SRI $\times$ media interaction was nonsignificant for total weight of marketable fruit (Fig. 4). Media affected total marketable yield, with significantly less fruit $\left(1 \mathrm{~kg} \cdot \mathrm{m}^{-2}\right.$ averaged across SRI) being produced on plants in perlite $\left(5.9 \mathrm{~kg} \cdot \mathrm{m}^{-2}\right)$ than in peat mix $\left(6.9 \mathrm{~kg} \cdot \mathrm{m}^{-2}\right)$ and pine bark $\left(6.8 \mathrm{~kg} \cdot \mathrm{m}^{-2}\right.$; Fig. 4). Responses to increased SRI were linear and negative for incidence of russet cracking, and cubic for radial cracking (Table 4). Among media, russet cracking was greatest in pine bark. Incidence of yellow spots was less than $0.5 \%$ and was unaffected by treatments. The percentage of fruit with blossom-end rot increased linearly (from $11 \%-33 \%$ ) with increased SRI (Table 4). Water and nutrient use efficiencies for marketable yield increased (less water and nutrients supplied per kilogram of fruit harvested) with significant cubic effects as SRI levels increased and efficiencies were unaffected by media (Table 5).

Total marketable yield: Expt. 2. The SRI $\times$ media interaction was significant for total weight of marketable fruit (Table 6). Linear reductions of weight and numbers of these fruit were attributed to increased SRI levels in the three media (Fig. 5). For SRI levels 1.7 to $9.7 \mathrm{~kW} \cdot \mathrm{min}^{-1} \cdot \mathrm{m}^{-2}$, yields from plants grown in peat mix decreased from $8.8 \mathrm{~kg} \cdot \mathrm{m}^{-2}$ to 3.6 $\mathrm{kg} \cdot \mathrm{m}^{-2}$. In perlite or pine bark, the average of both yields decreased from only $6.8 \mathrm{~kg} \cdot \mathrm{m}^{-2}$ to $3.6 \mathrm{~kg} \cdot \mathrm{m}^{-2}$ (Fig. 5). Plants grown in peat mix had 2.5 more marketable fruits $/ \mathrm{m}^{2}$ than the mean number of fruit produced in perlite and pine bark (Table 6). Plants irrigated with 74$1 / 2 \mathrm{~s}$ had significantly greater total marketable yield $\left(0.4 \mathrm{~kg} \cdot \mathrm{m}^{-2}\right)$ than with $37-\mathrm{s}$ (Table 6$)$.

The SRI $\times$ media and solution volume per event $\times$ media interactions were significant for the percentage of marketable yield based on total weight of marketable and unmarketable fruit combined (Table 6). With perlite, there was no effect of SRI on percentage of marketable yield (average across SRI levels, $88 \%$ ), but there were significant linear reductions in peat mix (from $93 \%$ to $74 \%$ ) and pine bark (from $93 \%$ to $81 \%$; data not shown). With $74-1 / 2$ s, percentage of marketable fruit was significantly higher in plants grown in perlite $(93 \%)$ or pine bark $(92 \%)$ than in peat mix $(85 \%)$, and the lowest percentage of marketable fruit was in any of the three media irrigated with 37-s (mean among media, $82 \%$; Fig. 6).

First-quality fruit: Expt. 2. The SRI $\times$ media interaction was significant for the total weight of first-quality fruit (Table 6). With pine bark, first-quality fruit weight had a significant quadratic response to increased SRI levels, but there were no significant responses in peat mix or perlite. Weight of first-quality fruit was significantly lower in plants grown in pine bark $\left(2.3 \mathrm{~kg} \cdot \mathrm{m}^{-2}\right)$ at $1.7 \mathrm{~kW} \cdot \mathrm{min}^{-1} \cdot \mathrm{m}^{-2} \mathrm{SRI}$, than in peat mix $\left(3.6 \mathrm{~kg} \cdot \mathrm{m}^{-2}\right)$ or perlite $\left(3.4 \mathrm{~kg} \cdot \mathrm{m}^{-2}\right.$; Fig. 5$)$. Volume per irrigation event did not affect first-quality fruit weight or number (Table 6). Number of first-quality fruit responded quadratically to increased SRI in all media, but there were fewer fruit (two fruit $/ \mathrm{m}^{2}$ less) in pine bark than in peat mix or perlite (Table 6).

Second quality: Fruit with russet and radial cracking, and with yellow spots: Expt. 2. Weight and number of secondquality fruit decreased linearly with increased SRI levels, were unaffected by volume per irrigation event, and were greater in peat mix and pine bark than in perlite (Table 6).

Plants in pine bark had the highest percentage of fruits with russet and radial cracks (based on total marketable yield), whereas the lowest incidence was in perlite (Table 7). The SRI $\times$ solution volume per event interaction was significant for the percentage of fruit with russet cracks (Table 7 ). With the increase of SRI levels, percentage of fruit with russet cracks decreased faster in plants irrigated with 37 -s (quadratic response) than with 74-1/2s (cubic response; Fig. 7A). Decreases were linear for percentages of fruit with radial cracks (from $42 \%$ to $11 \%$ ) and yellow spots (from $12 \%$ to $7 \%$ ) as SRI levels increased (Table 7). The incidence of yellow spots was unaffected by media and was almost twofold with $74-1 / 2$ s compared with 37-s (Table 7).

Number of fruit with blossom-end rot: Expt. 2. The SRI $\times$ solution volume per event and SRI $\times$ media interactions were significant for total number and for percentage (by number) of fruit with blossom-end rot (Table 7). In plants irrigated with $37-\mathrm{s}$, the percentage of fruit with blossom-end rot increased linearly from $15 \%$ to $46 \%$ (from $4.7-13.8$ fruit $/ \mathrm{m}^{2}$; data not shown) as SRI levels increased (Fig. 7B). With $74-1 / 2$ s, the percentage of fruit with blossom-end rot was unaffected by SRI levels and had an overall mean of $14 \%$ (4.0 fruit $/ \mathrm{m}^{2}$; Fig. 7B). The number of fruit with blossom-end rot increased linearly with increased SRI levels, from 3.9 to 12.9 fruit $/ \mathrm{m}^{2}$ for plants in peat mix, and from 3.1 to 9.6 fruit $/ \mathrm{m}^{2}$ for plants in pine bark (Fig. 8). 
Table 3. Total volumes of nutrient solution and total amounts of selected nutrients delivered to greenhouse-grown pepper plants in Expts. 1 and 2 (10 Oct. 1999 to 4 May $2000 ; 206 \mathrm{~d})$.

\begin{tabular}{|c|c|c|c|c|c|c|c|c|c|c|c|c|c|}
\hline \multirow{2}{*}{$\begin{array}{l}\text { Irrigation solar } \\
\text { radiation integral } \\
\left(\mathrm{kW} \cdot \mathrm{min}^{-1} \cdot \mathrm{m}^{-2}\right)\end{array}$} & \multirow{2}{*}{$\begin{array}{l}\text { Mean irrigation } \\
\text { event number } \\
\text { (no./day) }\end{array}$} & \multicolumn{2}{|c|}{$\begin{array}{c}\text { Total water } \\
\text { delivered }\left(\mathrm{L} \cdot \mathrm{m}^{-2}\right)\end{array}$} & \multicolumn{10}{|c|}{$\begin{array}{c}\text { Total nutrient } \\
\text { delivered }\left(\mathrm{g} \cdot \mathrm{m}^{-2}\right)\end{array}$} \\
\hline & & $\begin{array}{c}\text { Expts. } 1^{\mathrm{y}} \text { and } \\
2,{ }^{\times} 74 \mathrm{~mL} / \mathrm{event}\end{array}$ & $\begin{array}{c}\text { Expt. 2, } \\
37 \mathrm{~mL} / \text { event }\end{array}$ & $\mathrm{N}$ & $\mathrm{P}$ & $\mathrm{K}$ & $\mathrm{Ca}$ & $\mathrm{Mg}$ & $\mathrm{N}$ & $\mathrm{P}$ & $\mathrm{K}$ & $\mathrm{Ca}$ & $\mathrm{Mg}$ \\
\hline $3.7 \pm 0.42$ & $26 \pm 26$ & 1059 & 528 & 162 & 54 & 210 & 198 & 48 & 81 & 27 & 105 & 99 & 24 \\
\hline $5.7 \pm 0.42$ & $17 \pm 8$ & 675 & 339 & 102 & 36 & 132 & 126 & 30 & 51 & 18 & 66 & 63 & 15 \\
\hline $7.7 \pm 0.42$ & $12 \pm 5$ & 495 & 249 & 78 & 24 & 96 & 90 & 24 & 39 & 12 & 48 & 45 & 12 \\
\hline $9.7 \pm 0.42$ & $10 \pm 4$ & 393 & 195 & 60 & 18 & 78 & 72 & 18 & 30 & 9 & 39 & 36 & 9 \\
\hline
\end{tabular}

${ }^{\mathrm{z}}$ Mean set-point values of solar radiation input in an irrigation controller to initiate irrigation events $( \pm \mathrm{SD})$.

'Irrigation with $74 \mathrm{~mL} /$ event, solution with a standard nutrient concentration level. Plant density was three plants $/ \mathrm{m}^{2}$.

${ }^{x}$ Irrigation with $74 \mathrm{~mL} /$ event with a half-standard nutrient concentration level or $37 \mathrm{~mL} /$ event with a standard nutrient concentration level.

Solar radiation-based irrigation schedule determined combinations of nutrient concentration levels (standard and half-standard concentration) and volumes per irrigation event ( 74 and $37 \mathrm{~mL} / \mathrm{event})$.
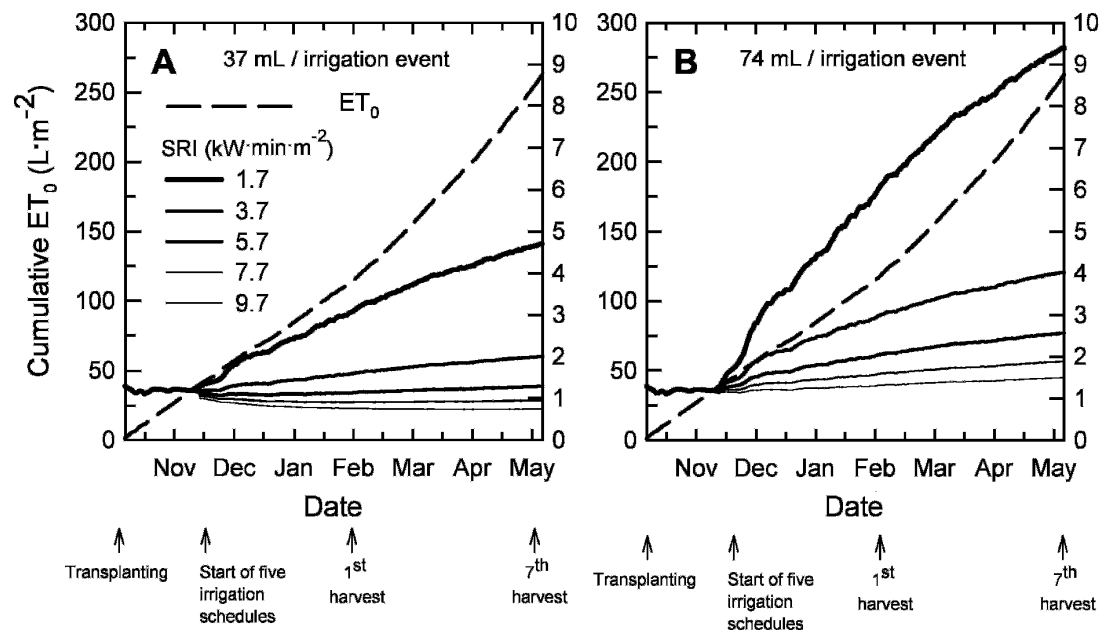

Fig. 3. (A, B) Cumulative daily reference evapotranspiration $\left(\mathrm{ET}_{0}\right)$ estimated inside the greenhouse (Penman-Monteith method) and ratios between cumulative water volumes from five solar radiationbased irrigation frequencies and cumulative $\mathrm{ET}_{0}$ when irrigation events delivered $37 \mathrm{~mL}(\mathbf{A})$ and $74 \mathrm{~mL}$ (B). Bell pepper crop period was 206 d, from 10 Oct. 1999 to 4 May 2000. SRI, solar radiation integral.

Plants in perlite produced equivalent numbers of fruit with blossom-end rot as SRI levels increased, and had an overall mean of 5.6 fruit $/ \mathrm{m}^{2}$ (19\% by number; Fig. 8$)$. Percentage of fruit with blossom-end rot in the significant SRI $\times$ media interaction (Table 7 ) was affected in a similar way as the number of fruit with this disorder (data not shown). At $9.7 \mathrm{~kW} \cdot \mathrm{min}^{-1} \cdot \mathrm{m}^{-2}$, percentages of fruit with blossom-end rot in peat mix $(42 \%)$ and perlite $(35 \%)$ were significantly higher than in plants grown in perlite $(21 \%)$. The solution volume per event $\times$ media interaction was significant for percentage of fruit with blossom-end rot (percent by number; Table 7). The percentages of blossom-end rot were highest in any media irrigated with 37-s compared with $74-1 / 2 \mathrm{~s}$, whereas the lowest were in perlite or pine bark (mean, 18\%; Fig. 9).

Total number of combined marketable and unmarketable fruit: Expt. 2. The SRI $\times$ media interaction was significant for the total number of fruit (Table 7). Total number of fruit decreased linearly as SRI level increased in plants in peat mix (from 36.1-29.4 fruit $/ \mathrm{m}^{2}$ ) and perlite (from $30.0-21.0$ fruit $/ \mathrm{m}^{2}$ ), but was equivalent at all SRI levels in plants in pine bark (overall mean across SRI, 27.5 fruit $/ \mathrm{m}^{2}$; Fig. 8). Total number of fruit was generally higher in plants in peat mix than in perlite or pine bark.

Marketable fruit water use efficiency: Expt. 2. The SRI $\times$ solution volume per event interaction was significant for water use efficiency (Table 8). Cubic responses for volumes $37-\mathrm{s}$ and $74-1 / 2 \mathrm{~s}$ were significant (Fig. 10A). At every SRI level, more water was delivered per kilogram of fruit harvested in plants irrigated with $74-1 / 2$ s than with 37 -s. Water use efficiency differences between the two volumes per irrigation event were large in plants irrigated at $1.7 \mathrm{~kW} \cdot \mathrm{min}^{-1} \cdot \mathrm{m}^{-2}(107 \%$ more water $/ \mathrm{kg}$ than with $37-\mathrm{s})$, and became smaller at higher SRI levels $(46 \%$ more water $/ \mathrm{kg}$ than with $37-\mathrm{s}$ at $9.7 \mathrm{~kW} \cdot \mathrm{min}^{-1} \cdot \mathrm{m}^{-2}$; Fig. 10A). The SRI $\times$ media interaction was significant for water use efficiency (Table 8), with cubic effects to SRI levels in perlite and pine bark, and quadratic effects in peat mix (Fig. 10B). Water use efficiency did not differ among media at SRI levels greater than 3.7 $\mathrm{kW} \cdot \mathrm{min}^{-1} \cdot \mathrm{m}^{-2}$. However, at the SRI level of $1.7 \mathrm{~kW} \cdot \mathrm{min}^{-1} \cdot \mathrm{m}^{-2}$, plants in peat mix used $216 \mathrm{~L} \cdot \mathrm{kg}^{-1}$ and were more efficient than pine bark $\left(267 \mathrm{~L} \cdot \mathrm{kg}^{-1}\right)$ and perlite $\left(285 \mathrm{~L} \cdot \mathrm{kg}^{-1}\right.$; Fig. $10 \mathrm{~B})$. The solution volume per event $\times$ media interaction was significant for water use efficiency (Table 8). Less water was deliv-

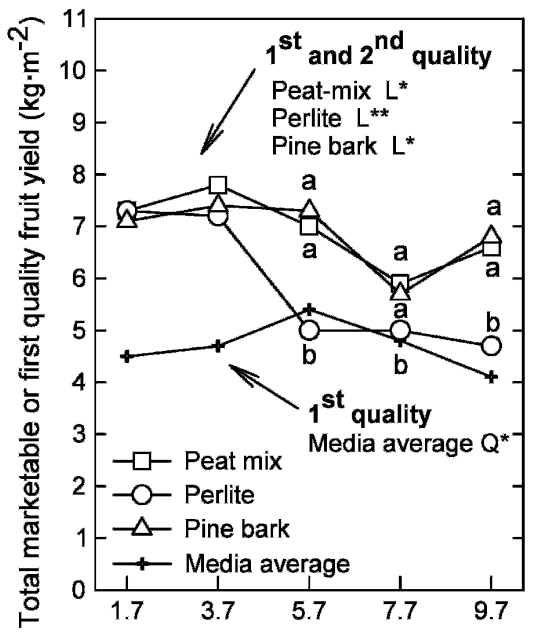

Irrigation solar radiation integral $\left(\mathrm{kW} \cdot \mathrm{min} \cdot \mathrm{m}^{-2}\right.$ )

Fig. 4. Total marketable bell pepper yield (first- and second-quality fruit) and first-quality fruit yield in greenhouse Expt. 1. Fruit were harvested 5 Feb. to 4 May 2000 from plants grown in three soilless media and with irrigation initiated at five levels of solar radiation integral (SRI). Media $(\mathrm{M})$ was significant $(P<0.05)$, but the SRI $\times M$ interaction was not $(P>0.05)$. $\mathrm{L}, \mathrm{Q}$, linear and quadratic effect respectively. ${ }^{*},{ }^{* *}$ Significant at $P<0.05$ and $P<0.01$ respectively. Means followed by the same letters within a radiation integral level, and within total marketable fruit, are not significantly different with Duncan's multiple range test at $5 \%$ level. When the $\mathrm{F}$ test was nonsignificant $(P>0.05)$ within a level of radiation integral, no letters were assigned to means. Regression equations for total marketable yield were $\mathrm{y}=7.91-0.33 \mathrm{x}, r^{2}=0.57$ (peat mix); $\mathrm{y}=$ $8.06-0.74 \mathrm{x}, r^{2}=0.81$ (perlite), and $\mathrm{y}=7.55$ $0.23 \mathrm{x}, r^{2}=0.28$ (pine bark); and for first-quality fruit (averaged among all media because media effect had a $P$ value of more than 0.05 ) was $\mathrm{y}=3.54+0.596 \mathrm{x}-0.055 \mathrm{x}^{2}, R^{2}=0.82$.

ered per kilogram of marketable fruit in plants grown in any media irrigated with 37-s (overall mean, $88 \mathrm{~L} \cdot \mathrm{kg}^{-1}$ ) than in those irrigated with $74-1 / 2 \mathrm{~S}$ (Fig. 11). With irrigation of $74-1 / 2 \mathrm{~s}$, water use efficiency was significantly different among media, with production of marketable fruit being more efficient in peat mix with significantly less water $\left(146 \mathrm{~L} \cdot \mathrm{kg}^{-1}\right)$ than in perlite $\left(177 \mathrm{~L} \cdot \mathrm{kg}^{-1}\right)$, and in pine bark $\left(166 \mathrm{~L} \cdot \mathrm{kg}^{-1}\right)$. 
Table 4. Marketable fruit yield of second quality and incidence of blossom-end rot in greenhouse-grown bell pepper in Expt. 1 as affected by solar radiation-based irrigation frequency and container media (harvest period, 5 Feb. to 4 May 2000).

\begin{tabular}{|c|c|c|c|c|}
\hline \multirow[b]{2}{*}{ Treatment } & \multicolumn{3}{|c|}{ Second-quality yield ${ }^{\mathrm{z}}$} & \multirow[b]{2}{*}{$\begin{array}{c}\text { Blossom-end rot } \\
\text { (\% by no.) }\end{array}$} \\
\hline & $\begin{array}{l}\text { Russet cracks } \\
\text { ( } \% \text { by no.) }\end{array}$ & $\begin{array}{c}\text { Radial cracks } \\
(\% \text { by no. })\end{array}$ & $\begin{array}{l}\text { Yellow spots } \\
\text { (\% by no.) }\end{array}$ & \\
\hline \multicolumn{5}{|c|}{ Irrigation SRI $\left(\mathrm{kW} \cdot \mathrm{min}^{-1} \cdot \mathrm{m}^{-2}\right)$} \\
\hline $1.7^{\mathrm{x}}$ & 21.2 & 28.8 & 0.7 & 11.4 \\
\hline 3.7 & 16.3 & 32.3 & 0.0 & 20.9 \\
\hline 5.7 & 9.6 & 15.6 & 0.0 & 23.5 \\
\hline 7.7 & 9.2 & 12.6 & 0.0 & 14.9 \\
\hline 9.7 & 7.7 & 24.9 & 1.7 & 32.6 \\
\hline Significance & $\mathrm{L}^{* * w}$ & $\mathrm{C}^{* *}$ & NS & $\mathrm{L}^{*}$ \\
\hline \multicolumn{5}{|l|}{ Media } \\
\hline Peat $\operatorname{mix}^{\mathrm{u}}$ & $8.9 \mathrm{~b}^{\mathrm{v}}$ & 24.2 & 0.6 & 20.5 \\
\hline Perlite & $10.2 \mathrm{~b}$ & 19.6 & 0.0 & 21.5 \\
\hline Pine bark & $19.3 \mathrm{a}$ & 24.8 & 0.8 & 20.1 \\
\hline Significance & $* *$ & NS & NS & NS \\
\hline Interaction: $\mathrm{SRI} \times \mathrm{M}$ & NS & NS & NS & NS \\
\hline
\end{tabular}

${ }^{\mathrm{z}}$ Marketable fruit included those of size extralarge (fruit diameter $>84.0 \mathrm{~mm}$ ), large $(76.0-83.9 \mathrm{~mm}$ ), medium $(64.0-75.9 \mathrm{~mm})$, and small $(56.0-63.9 \mathrm{~mm})$. This includes fruit with scar signs of russet or radial cracking, or that had yellow spots. Percentage based on total number of marketable fruit.

yPercentage of fruit with the disorder based on total number of harvested fruit (marketable and unmarketable fruit combined).

${ }^{\mathrm{x}}$ Mean set-point values of solar radiation input in an irrigation controller to initiate irrigation events. Mean number of irrigation events per day was $61,26,17,12$, and 10 respectively.

${ }^{\mathrm{w}} \mathrm{L}, \mathrm{Q}, \mathrm{C}$, significant linear, quadratic, and cubic effect respectively.

'Means followed by the same letter are not significantly different with Duncan's multiple range test at the $5 \%$ level.

un $11.3-\mathrm{dm}^{3}$ nursery pots.

NS,*,*** Nonsignificant and significant at $P \leq 0.05$ and $P \leq 0.01$, analysis of variance, respectively.

M, media; SRI, solar radiation integral.

Table 5. Water and nutrient use efficiencies for marketable fruit in greenhouse-grown bell pepper in Expt. 1 as affected by solar radiation-based irrigation frequency and container media.

\begin{tabular}{|c|c|c|c|c|c|c|}
\hline \multirow{2}{*}{$\begin{array}{l}\text { Irrigation SRI } \\
\left(\mathrm{kW} \cdot \mathrm{min}^{-1} \cdot \mathrm{m}^{-2}\right)\end{array}$} & \multirow{2}{*}{$\begin{array}{c}\text { Fruit yield } \\
\text { water use efficiency } \\
\left(\mathrm{L} \cdot \mathrm{kg}^{-1}\right)\end{array}$} & \multicolumn{5}{|c|}{$\begin{array}{c}\text { Fruit yield } \\
\text { nutrient use efficiency }\left(\mathrm{g} \cdot \mathrm{kg}^{-1}\right)\end{array}$} \\
\hline & & $\mathrm{N}$ & $\mathrm{P}$ & $\mathrm{K}$ & $\mathrm{Ca}$ & $\mathrm{Mg}$ \\
\hline $1.7^{x}$ & 347.9 & 53.2 & 17.8 & 69.2 & 65.0 & 16.9 \\
\hline 3.7 & 145.8 & 22.4 & 7.4 & 29.0 & 27.3 & 6.6 \\
\hline 5.7 & 117.5 & 17.7 & 6.3 & 22.9 & 21.8 & 5.2 \\
\hline 7.7 & 94.4 & 14.8 & 4.5 & 18.2 & 17.1 & 4.5 \\
\hline 9.7 & 68.5 & 10.5 & 3.1 & 13.7 & 12.6 & 3.2 \\
\hline Significance & $\mathrm{C}^{* * \mathrm{w}}$ & $\mathrm{C}^{* *}$ & $\mathrm{C}^{* *}$ & $\mathrm{C}^{* *}$ & $\mathrm{C}^{* *}$ & $\mathrm{C}^{* *}$ \\
\hline Media significance & NS & NS & NS & NS & NS & NS \\
\hline Interaction: $\mathrm{SRI} \times \mathrm{M}$ & NS & NS & NS & NS & NS & NS \\
\hline
\end{tabular}

${ }^{\mathrm{z}}$ Calculated as the total volume of nutrient solution delivered divided by the total weight of marketable fruit harvested (5 Feb. to 4 May 2000).

${ }^{y}$ Calculated as total weight of nutrient delivered to the plant divided by the total weight of marketable fruit harvested.

${ }^{\mathrm{x}}$ Mean set-point values of solar radiation input in an irrigation controller to initiate irrigation events. Mean number of irrigation events per day was $61,26,17,12$, and 10 respectively.

${ }^{\mathrm{w}} \mathrm{C}$, cubic effect.

NS,** Nonsignificant and significant at $P \leq 0.01$, analysis of variance.

M, media; SRI, solar radiation integral.

Marketable fruit nutrient use efficiency: Expt. 2. For every nutrient examined, plants irrigated with $74-1 / 2 \mathrm{~s}$ used lower amounts of nutrients per kilogram of marketable fruit (9.2\% by weight) than with 37 -s (Table 8 ). The SRI $\times$ media interaction was significant for nutrient use efficiency (Table 8). For every nutrient examined, use efficiencies had significant cubic effects to increased SRI in perlite and pine bark, and quadratic effects in peat mix (data not shown). Only at $1.7 \mathrm{~kW} \cdot \mathrm{min}^{-1} \cdot \mathrm{m}^{-2}$ were efficiencies significantly different among media (data not shown). At the SRI level of 1.7 $\mathrm{kW} \cdot \mathrm{min}^{-1} \cdot \mathrm{m}^{-2}$, plants in peat mix used $25 \%$ less nutrient per kilogram of marketable fruit growth, and first-quality fruit weight, but not total combined marketable and unmarketable fruit number (Silber et al., 2005b). Conversely, low irrigation frequency in container-grown peppers can reduce plant growth and total yield as a result of low water and nutrient supply to the roots and increase of EC from salt accumulation in the root media (Sonnenveld, 1979; 2002). In our experiments, increases in total marketable yield were attributed mainly to increases of second-quality fruit.

When plants received $74 \mathrm{~mL}$ of a solution with standard nutrient levels (in any media used), the quadratic response of first-quality fruit weight to SRI indicated that these plants benefited more by an irrigation with the $5.7 \mathrm{~kW} \cdot \mathrm{min}^{-1} \cdot \mathrm{m}^{-2} \mathrm{SRI}$ set point (mean, $17 \pm$ 8 events/day), which led to $5.4 \mathrm{~kg} \cdot \mathrm{m}^{-2}$ of firstquality fruit (Fig. 4). Higher irrigation frequencies led to reduced first-quality yield and a decrease in water and nutrient use efficiency (Table 5). Maintaining $74 \mathrm{~mL} /$ event, but with half the nutrient concentration levels through the entire crop season, appeared to reduce production of first-quality fruit to $\leq 3.6 \mathrm{~kg} \cdot \mathrm{m}^{-2}$ (Fig. 5), indicating this irrigation practice might not be advantageous in increasing high-quality fruit with this cultivar. Delivering $37-\mathrm{s}$ or $74-1 / 2$ s to peat mix or perlite and a wide range of irrigation schedules (water volumes that ranged from 65-823 L/plant, and nutrient amounts that varied up to six times) led to first-quality mean fruit yield across SRI levels of only $3.5 \mathrm{~kg} \cdot \mathrm{m}^{-2}$ (Table 5 and Fig. 5).

Fruit with cracking were found in all harvests, and no treatments prevented cracking. The pepper 'HA3378' had a thick pericarp (up to $9 \mathrm{~mm}$ measured in extralarge fruit of $242-345 \mathrm{~g} /$ fruit), and pepper cultivars with this trait have been reported to be more prone to cracking (Aloni et al., 1998, 1999). In a similar way to tomato, russet (or cuticle) cracking and radial cracking in pepper fruits are determined by water balance in the fruit (Aloni et al., 1998, 1999; Dorais et al., 2004; Ehret et al., 1993; Peet, 1992). High internal water pressure of epidermal cells can cause them to expand rapidly and leads to cuticle, or radial, cracks that usually occur at the blossom-end of the fruit (Aloni et al., 1998, 1999; Ehret et al., 1993). Increased fruit turgor pressure from high root pressure in media irrigated frequently, or with a low EC in the irrigation solution (as with $72-1 / 2 \mathrm{~s}$ ), may have been associated with the higher incidence of cracking in pepper fruit (Table 7 and Fig. 7). Furthermore, with increased SRI levels, the first irrigation in the morning was always delayed compared with lower SRI levels. This delay in irrigation can decrease water content and increase $\mathrm{EC}$ in the root media, and may lead to fewer incidences of fruit cracking, but implementing this practice may also increase incidence of blossom-end rot (An et al., 2005). A greenhouse environment with low nighttime temperatures and high relative humidity (such as $12{ }^{\circ} \mathrm{C}$ and $95 \%$ ) causes increases in water pressure in pepper fruit and could lead 
Table 6. Marketable fruit yield of greenhouse-grown bell pepper in Expt. 2 as affected by solar radiationbased irrigation frequency, volume per irrigation event and amount of nutrients, and container media (harvest period, 5 Feb. to 4 May 2000).

\begin{tabular}{|c|c|c|c|c|c|c|c|}
\hline \multirow[b]{2}{*}{ Treatment } & \multicolumn{3}{|c|}{ Total marketable yield ${ }^{\mathrm{z}}$} & \multicolumn{2}{|c|}{ First-quality yield ${ }^{\mathrm{y}}$} & \multicolumn{2}{|c|}{ Second-quality yield ${ }^{\mathrm{x}}$} \\
\hline & $\overline{\left(\mathrm{kg} \cdot \mathrm{m}^{-2}\right)}$ & $\left(\right.$ no. $\left./ \mathrm{m}^{2}\right)$ & $(\% \text { by } w t)^{v}$ & $\left(\mathrm{~kg} \cdot \mathrm{m}^{-2}\right)$ & $\overline{\left(\text { no. } / \mathrm{m}^{2}\right)}$ & $\left(\mathrm{kg} \cdot \mathrm{m}^{-2}\right)$ & $\left(\right.$ no. $\left./ \mathrm{m}^{2}\right)$ \\
\hline \multicolumn{8}{|c|}{ Irrigation SRI $\left(\mathrm{kW} \cdot \mathrm{min}^{-1} \cdot \mathrm{m}^{-2}\right)$} \\
\hline $1.7^{\mathrm{w}}$ & 7.5 & 27.0 & 90.9 & 3.1 & 11.4 & 4.3 & 15.6 \\
\hline 3.7 & 6.5 & 25.0 & 85.9 & 3.6 & 13.9 & 2.9 & 11.1 \\
\hline 5.7 & 5.8 & 23.4 & 87.0 & 3.7 & 14.6 & 2.2 & 8.8 \\
\hline 7.7 & 4.7 & 19.5 & 85.0 & 3.6 & 15.3 & 1.0 & 4.3 \\
\hline 9.7 & 3.6 & 15.9 & 81.0 & 2.9 & 13.0 & 0.7 & 2.9 \\
\hline Significance & $\mathrm{L}^{* * u}$ & $\mathrm{~L}^{* *}$ & $\mathrm{~L}^{*}$ & $\mathrm{Q}^{*}$ & $\mathrm{Q}^{* *}$ & $\mathrm{~L}^{* *}$ & $\mathrm{~L}^{* *}$ \\
\hline \multicolumn{8}{|c|}{ Solution volume per event (mL-concn) } \\
\hline $37-\mathrm{s}^{\mathrm{t}}$ & 5.4 & 22.0 & 82.1 & 3.3 & 13.9 & 2.1 & 8.1 \\
\hline $74-\frac{1}{2} \mathrm{~s}$ & 5.8 & 22.3 & 89.8 & 3.4 & 13.4 & 2.4 & 9.0 \\
\hline Significance & *s & NS & $* *$ & NS & NS & NS & NS \\
\hline \multicolumn{8}{|l|}{ Media } \\
\hline Peat $\mathrm{mix}^{\mathrm{s}}$ & 6.0 & $23.8 \mathrm{a}^{\mathrm{r}}$ & 83.1 & 3.5 & $14.0 \mathrm{a}$ & $2.5 \mathrm{a}$ & $9.7 \mathrm{a}$ \\
\hline Perlite & 5.3 & $21.3 \mathrm{~b}$ & 87.8 & 3.5 & $14.6 \mathrm{a}$ & $1.8 \mathrm{~b}$ & $6.7 \mathrm{~b}$ \\
\hline Pine bark & 5.5 & $21.4 \mathrm{~b}$ & 86.9 & 3.1 & $12.2 \mathrm{~b}$ & $2.4 \mathrm{a}$ & $9.2 \mathrm{a}$ \\
\hline Significance & $* *$ & $* *$ & $* *$ & $* *$ & $* *$ & $* *$ & $* *$ \\
\hline \multicolumn{8}{|l|}{ Interactions } \\
\hline $\mathrm{SRI} \times \mathrm{V}$ & NS & NS & NS & NS & NS & NS & NS \\
\hline $\mathrm{SRI} \times \mathrm{M}$ & ** & NS & ** & $*$ & NS & NS & NS \\
\hline $\mathrm{V} \times \mathrm{M}$ & NS & NS & $*$ & NS & NS & NS & NS \\
\hline $\mathrm{SRI} \times \mathrm{V} \times \mathrm{M}$ & NS & NS & NS & NS & NS & NS & NS \\
\hline
\end{tabular}

${ }^{\mathrm{z}}$ Marketable fruit included those of size extralarge (fruit diameter $>84.0 \mathrm{~mm}$ ), large $(76.0-83.9 \mathrm{~mm}$ ), medium $(64.0-75.9 \mathrm{~mm})$, and small $(56.0-63.9 \mathrm{~mm})$. Combined fruit of first quality and second quality. ${ }^{\mathrm{y}}$ First-quality fruit were free of defects.

${ }^{\mathrm{x}}$ Second-quality fruit had scar signs of russet or radial cracking, or had yellow spots.

${ }^{\text {w}}$ Mean set-point values of solar radiation input in an irrigation controller to initiate irrigation events. Mean number of irrigation events per day was $61,26,17,12$, and 10 respectively.

${ }^{v}$ Percentage based on total weight of fruit harvested (marketable and unmarketable fruit combined).

${ }^{\text {"L, }} \mathrm{Q}$, significant linear and quadratic effect respectively.

${ }^{t}$ Volumes per irrigation event were $37 \mathrm{~mL}$ of a solution with a standard nutrient concentration level (37-s) and $74 \mathrm{~mL}$ of a solution with half the standard nutrient concentration level (74-1/2s).

sIn $11.3-\mathrm{dm}^{3}$ nursery pots.

'Means followed by the same letter are not significantly different with Duncan's multiple range test at the $5 \%$ level.

NS,*,*** Nonsignificant and significant at $P \leq 0.05$ and $P \leq 0.01$, analysis of variance, respectively. $\mathrm{M}$, media; SRI, solar radiation integral; $\mathrm{V}$, solution volume per event.

to fruit cracking (Aloni et al., 1998, 1999; Yao et al., 2000). In Expts. 1 and 2, cool nights and high relative humidity were common environmental conditions during the spring. The mean minimum temperature and mean maximum relative air humidity during harvest months were February, $10.9^{\circ} \mathrm{C}$ and $96 \%$; March, $13.5{ }^{\circ} \mathrm{C}$ and $96 \%$; April, $12.3{ }^{\circ} \mathrm{C}$ and $93 \%$; and May, $18.6{ }^{\circ} \mathrm{C}$ and $93 \%$. Increased solar radiation after January may also have contributed to fruit cracking, because high solar radiation levels increase fruit shrinkage, which is correlated with more fruit cracking in pepper (Yao et al., 2000). Decreasing root pressure to decrease fruit cracking could be done by avoiding earlymorning and late-day irrigation, and, if economically feasible, heating during the nights of late winter and spring to decrease humidity (to $70 \%-80 \%$ ) (Portree, 1996), and shading plants during periods of high radiation.

Differences in incidences of fruit cracking among media might be explained by day/night variations in moisture content and EC in each media. Pine bark with the particle size used in this experiment generally led to a higher incidence of fruit cracking than did perlite or peat mix. Pine bark is an inexpensive media in Florida and is commonly used in greenhousegrown cucumber and pepper production. Pine bark with smaller particle size than the one used in this experiment has higher waterholding capacity and cation exchange capacity (Burés, 1997), which might improve pepper fruit yield and fruit quality.

Fruit with yellow spots were picked only in the last harvest (4 May). Fruit with this disorder in plants that received solutions with standard nutrient concentration levels were almost absent with $74 \mathrm{~mL}$ /event $(0.5 \%)$ and were low with $37 \mathrm{~mL} /$ event $(7.3 \%$; Tables 4 and 7). With $74 \mathrm{~mL} /$ event at half concentration levels, incidence increased to $13 \%$. With both volumes in Expt. 1 the incidence increased with irrigation frequency. Conditions that increase root pressure were reported as factors that led to the appearance of yellow spots in tomato and pepper (de Kreij et al., 1992; Portree, 1996). Susceptibility to yellow spots also varies among pepper cultivars, but the causes of this disorder are not yet clear (Aloni et al., 1994; Wien, 1997). Calcium oxalate crystals have been found in the yellow spots of pepper fruits with this disorder (Aloni et al., 1994) and in tomato, where the disorder is known as golden speck (de Kreij et al., 1992). In our experiments, an increased EC in the media from low irrigation frequency, and with standard nutrient concentration levels

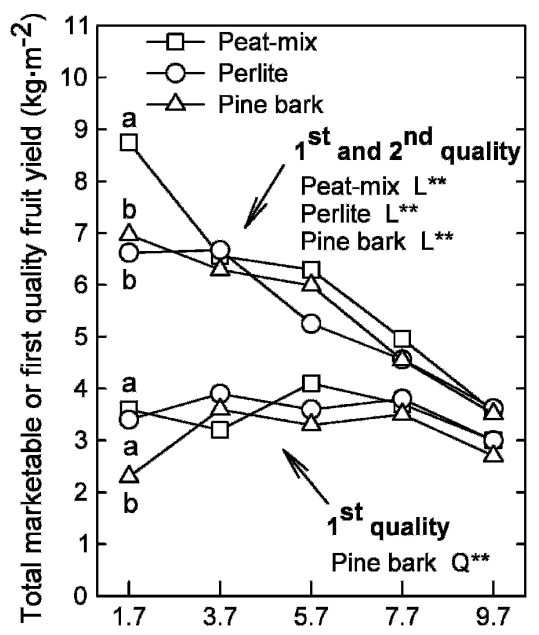

Irrigation solar radiation integral $\left(\mathrm{kW} \cdot \mathrm{min} \cdot \mathrm{m}^{-2}\right)$

Fig. 5. Total marketable bell pepper yield (first- and second-quality fruit) and first-quality fruit yield in greenhouse Expt. 2. Fruit were harvested 5 Feb. to 4 May 2000 from plants grown in three soilless media and with irrigation initiated at five levels of solar radiation integral. Means followed by the same letters within a radiation integral level, and within first-quality fruit or total marketable fruit, are not significantly different with Duncan's multiple range test at the $5 \%$ level. When the $\mathrm{F}$ test was nonsignificant $(P>0.05)$ within a level of radiation integral, no letters were assigned to means. $\mathrm{L}$, $\mathrm{Q}$, linear and quadratic effect respectively for the corresponding media. ${ }^{* *}$ Significant at $1 \%$ of probability. Regression equations for total marketable yield were $\mathrm{y}=9.44-0.599 \mathrm{x}, r^{2}=$ 0.96 (peat mix); $\mathrm{y}=7.66-0.406 \mathrm{x}, r^{2}=0.94$ (perlite), and $\mathrm{y}=7.93-0.433 \mathrm{x}, r^{2}=0.95$ (pine bark); and for first-quality fruit in pine bark was $\mathrm{y}=1.26+0.788 \mathrm{x}-0.066 \mathrm{x}^{2}, R^{2}=0.82$ (there were no significant responses with peat mix or perlite).

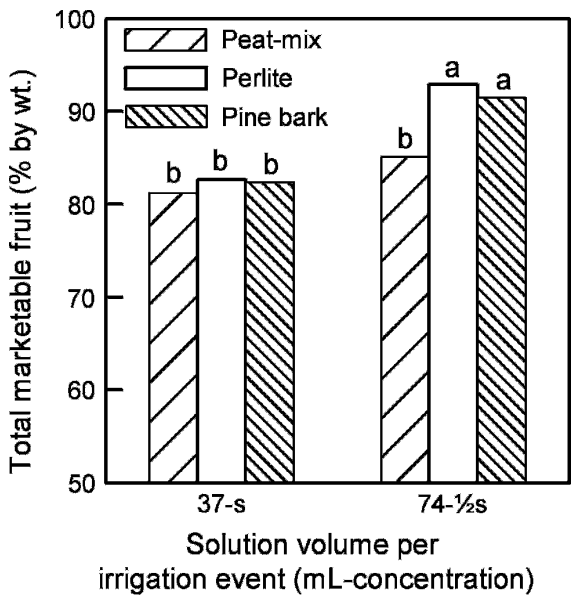

Fig. 6. Percentage of total marketable bell pepper fruit yield (by weight) in greenhouse Expt. 2. Fruit were harvested 5 Feb. to 4 May 2000 from plants grown in three soilless media and with irrigation events that delivered $37 \mathrm{~mL}$ of a solution with standard nutrient concentration levels (37-s) or $74 \mathrm{~mL}$ with half the concentration levels of nutrients $(74-1 / 2 \mathrm{~s})$. Bars with the same letter are not significantly different with Duncan's multiple range test at the 5\% level. 
Table 7. Second-quality fruit, fruit with blossom-end rot, and combined total marketable and unmarketable fruit in greenhouse-grown bell pepper in Expt. 2 as affected by solar radiation-based irrigation frequency, volume per irrigation event and amount of nutrients, and container media (harvest period, 5 Feb. to 4 May 2000).

\begin{tabular}{|c|c|c|c|c|c|c|}
\hline \multirow{3}{*}{$\begin{array}{l}\text { Irrigation SRI } \\
\left(\mathrm{kW} \cdot \mathrm{min}^{-1} \cdot \mathrm{m}^{-2}\right)\end{array}$} & \multicolumn{3}{|c|}{ Marketable fruit second quality ${ }^{z}$} & \multirow{2}{*}{\multicolumn{2}{|c|}{ Blossom-end $\operatorname{rot}^{\mathrm{y}}$}} & \multirow{3}{*}{$\begin{array}{c}\text { Total } \\
\left(\text { no. } / \mathrm{m}^{2}\right)\end{array}$} \\
\hline & \multirow{2}{*}{$\begin{array}{l}\text { Russet cracks } \\
\text { (\% by no.) }\end{array}$} & \multirow{2}{*}{$\begin{array}{l}\text { Radial cracks } \\
\text { (\% by no.) }\end{array}$} & \multirow{2}{*}{$\begin{array}{l}\text { Yellow spots } \\
(\% \text { by no.) }\end{array}$} & & & \\
\hline & & & & $\left(\right.$ no. $\left./ \mathrm{m}^{2}\right)$ & (\% by no.) & \\
\hline $1.7^{\mathrm{x}}$ & 35.1 & 41.6 & 11.9 & 4.2 & 13.5 & 31.3 \\
\hline 3.7 & 23.2 & 26.7 & 11.6 & 6.7 & 20.2 & 31.7 \\
\hline 5.7 & 12.0 & 23.8 & 12.8 & 5.9 & 19.2 & 29.3 \\
\hline 7.7 & 4.8 & 15.0 & 7.7 & 7.5 & 25.1 & 27.0 \\
\hline 9.7 & 4.4 & 10.5 & 6.7 & 9.2 & 32.9 & 25.1 \\
\hline Significance & $\mathrm{L}^{* * \mathrm{w}}$ & $\mathrm{L}^{* *}$ & $\mathrm{~L}^{*}$ & $\mathrm{~L}^{* *}$ & $\mathrm{~L}^{* *}$ & $\mathrm{~L}^{* *}$ \\
\hline \multicolumn{7}{|c|}{ Solution volume per event (mL-concn) } \\
\hline $37-s^{v}$ & 14.3 & 24.5 & 7.3 & 9.4 & 30.0 & 31.4 \\
\hline $74-1 / 2 \mathrm{~S}$ & 17.5 & 22.6 & 12.9 & 4.0 & 14.3 & 26.3 \\
\hline Significance & $* *$ & NS & $* *$ & $* *$ & $* *$ & $* *$ \\
\hline \multicolumn{7}{|l|}{ Media } \\
\hline Peat $\operatorname{mix}^{\mathrm{u}}$ & $16.4 \mathrm{~b}^{\mathrm{t}}$ & $24.4 \mathrm{~b}$ & 12.2 & 8.4 & 26.0 & 32.2 \\
\hline Perlite & $11.9 \mathrm{c}$ & $18.6 \mathrm{c}$ & 9.4 & 5.6 & 19.3 & 26.9 \\
\hline Pine bark & $19.4 \mathrm{a}$ & $27.6 \mathrm{a}$ & 8.8 & 6.0 & 21.2 & 27.5 \\
\hline Significance & $* *$ & $* *$ & NS & $* *$ & $*$ & $* *$ \\
\hline \multicolumn{7}{|l|}{ Interactions } \\
\hline $\mathrm{SRI} \times \mathrm{V}$ & $* *$ & NS & NS & $*$ & $*$ & NS \\
\hline $\mathrm{SRI} \times \mathrm{M}$ & NS & NS & NS & $* *$ & $* *$ & $* *$ \\
\hline $\mathrm{V} \times \mathrm{M}$ & NS & NS & NS & NS & $*$ & NS \\
\hline $\mathrm{SRI} \times \mathrm{V} \times \mathrm{M}$ & NS & NS & NS & NS & NS & NS \\
\hline
\end{tabular}

${ }^{\mathrm{z}}$ Marketable fruit of second quality included those of size extralarge (fruit diameter $>84.0 \mathrm{~mm}$ ), large $(76.0-83.9 \mathrm{~mm})$, medium $(64.0-75.9 \mathrm{~mm})$, and small $(56.0-63.9 \mathrm{~mm})$ that had scar signs of russet or radial cracking or that had yellow spots. Some fruit had more than one fruit disorder. Percentage based on total number of marketable fruit (first- and second-quality fruit combined) harvested.

${ }^{y}$ Fruit with blossom-end rot disorder symptoms. Percentage based on total number of harvested fruit (marketable and unmarketable fruit combined).

Mean set-point values of solar radiation input in an irrigation controller to initiate irrigation events. Mean number of irrigation events per day was $61,26,17,12$, and 10 respectively.

${ }^{\mathrm{w}} \mathrm{L}$, significant linear effect.

${ }^{v}$ Volumes per irrigation event were $37 \mathrm{~mL}$ of a solution with a standard nutrient concentration level (37-s) and $74 \mathrm{~mL}$ of a solution with half the standard nutrient concentration level $(74-1 / 2 \mathrm{~s})$.

un $11.3-\mathrm{dm}^{3}$ nursery pots.

'Means followed by the same letter are nonsignificant with Duncan's multiple range test at the 5\% level of significance.

NS,****Nonsignificant and significant at $P \leq 0.05$ and $P \leq 0.01$, analysis of variance, respectively.

$\mathrm{M}$, media; SRI, solar radiation integral; $\mathrm{V}$, solution volume per event.

could have led to the lower incidence of the disorder. With tomato irrigated under a radiation-based schedule, an increase in irrigation and EC in the solution (from a mean of 2.8 to one of $3.6 \mathrm{mS} \cdot \mathrm{cm}^{-1}$ ) were found to reduce incidence of gold specks (Chrétien et al., 2000). Aloni et al. (1994) reported a higher incidence of this fruit disorder in pepper plants irrigated with high $\mathrm{N}$ levels ( 250 vs. $100 \mathrm{mg} \cdot \mathrm{L}^{-1} \mathrm{f} \mathrm{N}$ ) during summer in Israel. In our experiments, higher temperatures near crop termination and the supply of high volumes of nutrient solution, with $\mathrm{N}$ concentration levels up to $160 \mathrm{mg} \cdot \mathrm{L}^{-1}$, could have induced the development of yellow spots in fruit of this sensitive cultivar.

Lower standard nutrient concentration levels, although conducive to fruit cracking and yellow spots, increased the percentage of marketable fruit (by 10\% in weight) and led to a reduced incidence of blossom-end rot (by $14 \%$ in number), particularly with lower irrigation frequency and with perlite and pine bark (media with lower water-holding capacity than peat mix; (Figs. 6, 7, and 9). Blossomend rot developed in small green fruit (diameter, $3-4 \mathrm{~cm}$ ) on upper plant nodes and was removed from plants during the last two

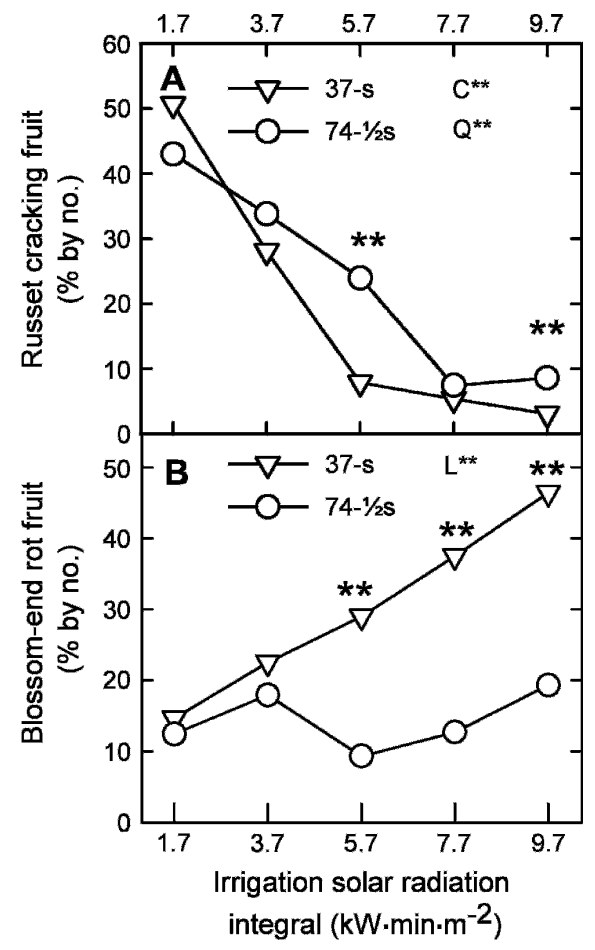

Fig. 7. (A, B) Percentage of bell pepper fruit in greenhouse Expt. 2 with russet cracks (A; by number, from total marketable fruit) and with blossom-end rot $(\mathbf{B}$; by number, from total fruit). Plants received $37 \mathrm{~mL}$ of a solution with standard nutrient concentration levels (34-s) or $74 \mathrm{~mL}$ with half the concentration levels of nutrients $(74-1 / 2 \mathrm{~s})$, with irrigation events initiated at five levels of solar radiation integral. ${ }^{* * *}$ Significant at $P<0.01$. When the $\mathrm{F}$ test was nonsignificant $(P>0.05)$ within a level of radiation integral, no symbol was assigned to means. L, Q, C, linear, quadratic, and cubic effects respectively for the corresponding volume per irrigation event.

harvests (4 Apr. and 4 May) after periods of high air temperature (up to $37{ }^{\circ} \mathrm{C}$ during afternoon hours) and solar radiation. Water stress (i.e., a low frequency of irrigation events) and osmotic stress (i.e., salts accumulated in the media) reduce $\mathrm{Ca}$ transport to the pepper fruit, particularly to the distal end region, where blossom-end rot develops (Geraldson, 1957; Marcelis and Ho, 1999; Silber et al., 2005b). Fruit 2 to 3 weeks after anthesis are the most susceptible to Ca deficiency, and, under high temperatures, transport of $\mathrm{Ca}$ to fruit is low, and much of the $\mathrm{Ca}$ is transported to leaves by transpiration (Ho et al., 1993; Marcelis and Ho, 1999). In our experiments, little or no solution drained from the plant containers irrigated with $37 \mathrm{~mL} /$ event and SRI levels greater than 3.7 $\mathrm{kW} \cdot \mathrm{min}^{-1} \cdot \mathrm{m}^{-2}$. A surplus of water, as with $74-1 / 2 \mathrm{~s}$, most likely helped avoid high EC levels in media with few irrigation events per day. Fewer irrigation events could have provided plants with sufficient water and $\mathrm{Ca}$, and could have prevented an increased incidence of blossom-end rot. The EC in the media solution from less irrigation may have been lower in perlite than in pine bark and peat mix, and this may explain why blossom-end rot in plants grown in perlite did not increase at higher levels of SRI (Fig. 7). The Ca concentration level in the solution with standard concentration levels was $190 \mathrm{mg} \cdot \mathrm{L}^{-1}$, which is considered adequate for avoiding blossomend rot (Geraldson, 1957; Sonnenveld, 2002).

With any media used, the mean set point near $5.7 \mathrm{~kW} \cdot \mathrm{min}^{-1} \cdot \mathrm{m}^{-2}$ (a daily mean of 17 irrigation events) and $74 \mathrm{~mL}$ at standard nutrient concentration levels appeared to contribute to greater blemish-free fruit yield than delivering $37 \mathrm{~mL} /$ event, or a halfconcentrated $74 \mathrm{~mL} /$ event, scheduled with SRI means within the range of 9.7 to 1.7 $\mathrm{kW} \cdot \mathrm{min}^{-1} \cdot \mathrm{m}^{-2}$ (10-61 events/day; Figs. 4 and 5). However, repeated experiments that include all treatments, and measure irrigation leachate volume and EC in plant containers, are required to develop practical irrigation management recommendations for growers. These determinations will allow calculating local crop coefficients for greenhouse-grown peppers in soilless media and using them in model-based irrigation management. Using daily $\mathrm{ET}_{0}$ to estimate daily irrigation volumes had relatively low 


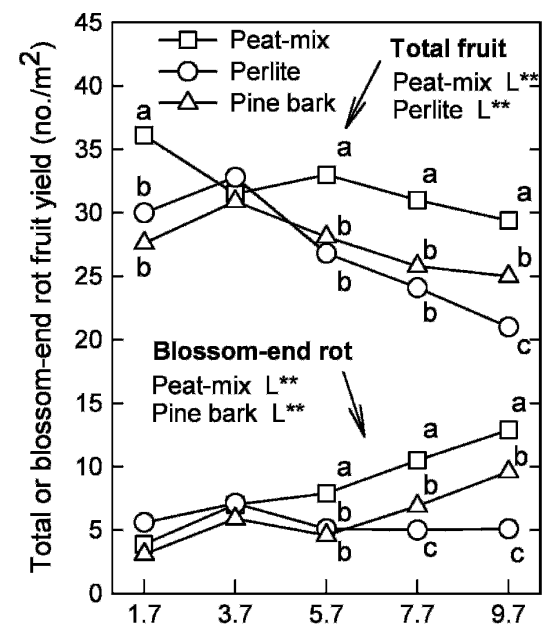

Irrigation solar radiation integral $\left(\mathrm{kW} \cdot \mathrm{min} \cdot \mathrm{m}^{-2}\right)$

Fig. 8. Total number of bell pepper fruit and fruit with blossom-end rot in greenhouse Expt. 2. Fruit were harvested 5 Feb. to 4 May 2000 from plants grown in three soilless media and with irrigation initiated at five levels of solar radiation integral. Means followed by the same letter within a radiation integral level and within a fruit quality category (total fruit or blossomend rot) are not significantly different with Duncan's multiple range test at the 5\% level. When the $\mathrm{F}$ test was nonsignificant $(P>0.05)$ within a level of radiation integral, no symbol was assigned to means. L, linear effect for the corresponding media. ${ }^{* *}$ Significant at $1 \%$ of probability.

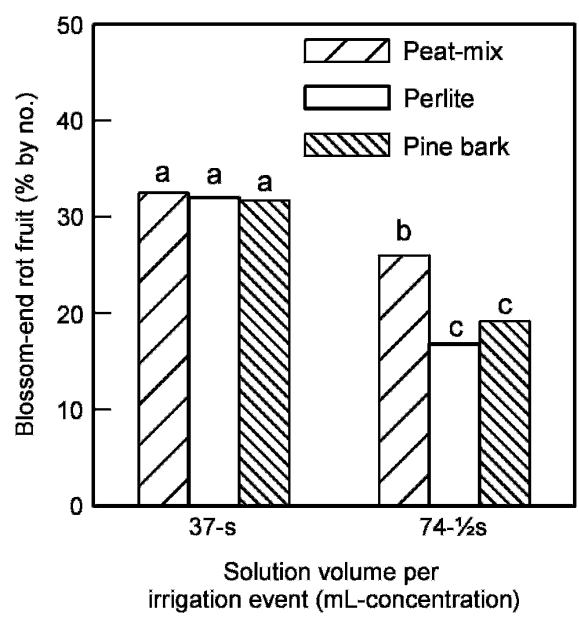

Fig. 9. Percentage of bell pepper fruit with blossom-end rot (by number) in greenhouse Expt. 2. Fruit were harvested 5 Feb. to 4 May 2000 from plants grown in three soilless media and with irrigation events that delivered 37 $\mathrm{mL}$ of a solution with standard nutrient concentration levels (37-s) or $74 \mathrm{~mL}$ with half the concentration levels of nutrients $(74-1 / 2 \mathrm{~s})$. Bars with the same letter are not significantly different with Duncan's multiple range test at the $5 \%$ level.

$r^{2}$ values (0.57-0.61). Moreover, irrigation controllers that allow nutrient levels to be changed during the day, and that use plant or media-based information in addition to solar

Table 8. Water and nutrient use efficiencies for marketable fruit harvested in greenhouse-grown bell pepper in Expt. 2 as affected by solar radiation-based irrigation frequency, volume per irrigation event and amount of nutrients, and container media.

\begin{tabular}{|c|c|c|c|c|c|c|}
\hline \multirow{2}{*}{$\begin{array}{l}\text { Irrigation SRI } \\
\left(\mathrm{kW} \cdot \mathrm{min}^{-1} \cdot \mathrm{m}^{-2}\right)\end{array}$} & \multirow{2}{*}{$\begin{array}{l}\text { Fruit yield water use } \\
\text { efficiency }^{\mathrm{z}}\left(\mathrm{L} \cdot \mathrm{kg}^{-1}\right)\end{array}$} & \multicolumn{5}{|c|}{ Fruit yield nutrient use efficiency ${ }^{\mathrm{y}}\left(\mathrm{g} \cdot \mathrm{kg}^{-1}\right)$} \\
\hline & & $\mathrm{N}$ & $\mathrm{P}$ & $\mathrm{K}$ & $\mathrm{Ca}$ & $\mathrm{Mg}$ \\
\hline $1.7^{\mathrm{x}}$ & 256.3 & 26.0 & 8.7 & 33.8 & 31.7 & 8.2 \\
\hline 3.7 & 123.0 & 12.7 & 4.2 & 16.4 & 15.5 & 3.8 \\
\hline 5.7 & 87.9 & 9.0 & 3.2 & 11.6 & 11.1 & 2.6 \\
\hline 7.7 & 79.2 & 8.5 & 2.6 & 10.5 & 9.8 & 2.6 \\
\hline 9.7 & 80.9 & 8.8 & 2.6 & 11.4 & 10.5 & 2.6 \\
\hline Significance & $\mathrm{C}^{* * \mathrm{w}}$ & $\mathrm{C}^{* *}$ & $\mathrm{C}^{* *}$ & $\mathrm{C}^{* *}$ & $\mathrm{C}^{* *}$ & $\mathrm{C}^{* *}$ \\
\hline \multicolumn{7}{|c|}{ Solution volume per event (mL-concn) } \\
\hline $37-\mathrm{s}^{\mathrm{v}}$ & 87.7 & 13.4 & 4.4 & 17.3 & 16.3 & 4.1 \\
\hline $74-1 / 2 \mathrm{~S}$ & 163.2 & 12.5 & 4.1 & 16.1 & 15.2 & 3.8 \\
\hline Significance & $* *$ & * & $*$ & * & * & $*$ \\
\hline \multicolumn{7}{|l|}{ Media } \\
\hline Peat mix & 114.4 & 11.9 & 3.9 & 15.4 & 14.5 & 3.7 \\
\hline Perlite & 133.4 & 13.7 & 4.5 & 17.6 & 16.5 & 4.2 \\
\hline Pine bark & 128.6 & 13.3 & 4.4 & 17.2 & 16.2 & 4.1 \\
\hline Significance & $* *$ & $* *$ & $* *$ & $* *$ & $* *$ & $* *$ \\
\hline \multicolumn{7}{|l|}{ Interaction } \\
\hline $\mathrm{SRI} \times \mathrm{V}$ & $* *$ & NS & NS & NS & NS & NS \\
\hline $\mathrm{SRI} \times \mathrm{M}$ & ** & ** & $* *$ & ** & ** & ** \\
\hline $\mathrm{V} \times \mathrm{M}$ & $* *$ & NS & NS & NS & NS & NS \\
\hline SRI $\times \mathrm{V} \times \mathrm{M}$ & NS & NS & NS & NS & NS & NS \\
\hline
\end{tabular}

${ }^{2}$ Calculated as the total volume of nutrient solution delivered divided by the total weight of marketable fruit harvested (5 Feb. to 4 May 2000).

${ }^{y}$ Calculated as the total weight of nutrient delivered to the plant divided by the total weight of marketable fruit harvested.

${ }^{\mathrm{x}}$ Mean set-point values of solar radiation input in an irrigation controller to initiate irrigation events. Mean number of irrigation events per day was $61,26,17,12$, and 10 respectively.

${ }^{\mathrm{w}} \mathrm{C}$, significant cubic effect.

volumes per irrigation event were $37 \mathrm{~mL}$ of a solution with a standard nutrient concentration level (37-s) and $74 \mathrm{~mL}$ of a solution with half the standard nutrient concentration level $(74-1 / 2 \mathrm{~s})$.

"In $11.3-\mathrm{dm}^{3}$ nursery pots.

NS, ${ }^{* * *}$ Nonsignificant and significant at $P \leq 0.05$ and $P \leq 0.01$, analysis of variance.

$\mathrm{M}$, media; SRI, solar radiation integral; $\mathrm{V}$, solution volume per event.

radiation might be more effective for increasing fruit quality (de Kreij et al., 2005; Ehret et al., 2001; Kläring, 2001; Shelford et al., 2004).

Soilless-grown crops may consume between 860 and $1140 \mathrm{~L} \cdot \mathrm{m}^{-2}$ per year based on average transpiration rates and an approximate $30 \%$ drainage from the plant containers (Shröder and Lieth, 2002). These volumes depend on numerous factors, such as greenhouse location and structure, crop season and period, and growing systems. Drainage can be as high as $50 \%$ during late spring and summer. The total irrigation volume supplied to soilless media with $5.7 \mathrm{~kW} \cdot \mathrm{min}^{-1} \cdot \mathrm{m}^{-2}$ and $74 \mathrm{~mL} /$ event, $675 \mathrm{~L} \cdot \mathrm{m}^{-2}$, with a daily delivery (mean $\pm \mathrm{SD}$ ) of $3.2 \pm 1.7 \mathrm{~L} /$ plant, was 2.6 times the $\mathrm{ET}_{0}$ inside the greenhouse. This total irrigation volume was greater than volumes delivered to peppers grown in the native soil or sand-soil mix in unheated greenhouses in other warm-climate regions where plant density was two plants $/ \mathrm{m}^{2}$ (within a range of $350-600 \mathrm{~L} \cdot \mathrm{m}^{-2}$ ) (Chartzoulakis and Drosos, 1997; Fernández et al., 2001, 2005; Pérez Martínez and Carreño Sánchez, 1996), but was lower than the estimated 800 to $1000 \mathrm{~L} \cdot \mathrm{m}^{-2}$ reported for peppers at 2.5 plants $/ \mathrm{m}^{2}$ in sand-soil mix (Alarcón Vera, 1996).

We observed fruit disorders commonly present in soilless-grown pepper plants in passive ventilated greenhouses and reported how their incidence can be affected by fertigation management and media. High frequency of irrigation is recommended only if yield of first-quality fruit could be increased, and if large volumes of water and amounts of nutrients drained from the plant containers (not measured consistently in the current experiments) could be recycled into the same or another crop. Higher nutrient concentration levels than those used as standard in these experiments may affect pepper fruit yield and quality differently. Irrigation and fertilization management are not the only practices to minimize fruit disorders in peppers grown in passively ventilated greenhouses in subtropical regions with mild winters. An increase of yield of first-quality fruit might be possible using low-cost technologies that can modify the environment to avoid extremes in low and high temperature, radiation, and humidity that are conducive to fruit disorders (such as a single polyethylene layer in the roof and screen systems, temperature-activated side curtains, and heating systems near the plant container). The selection of pepper cultivars with low susceptibility to fruit cracking (Aloni et al., 1998), yellow spots (Aloni et al., 1994), and blossom-end rot (Marcelis and Ho, 1999) is also a simple way to increase high-quality marketable yield. Overall marketable yields can also be increased with a longer harvest period resulting from earlier plantings, such as in late July or early August (Jovicich et al., 2005). 


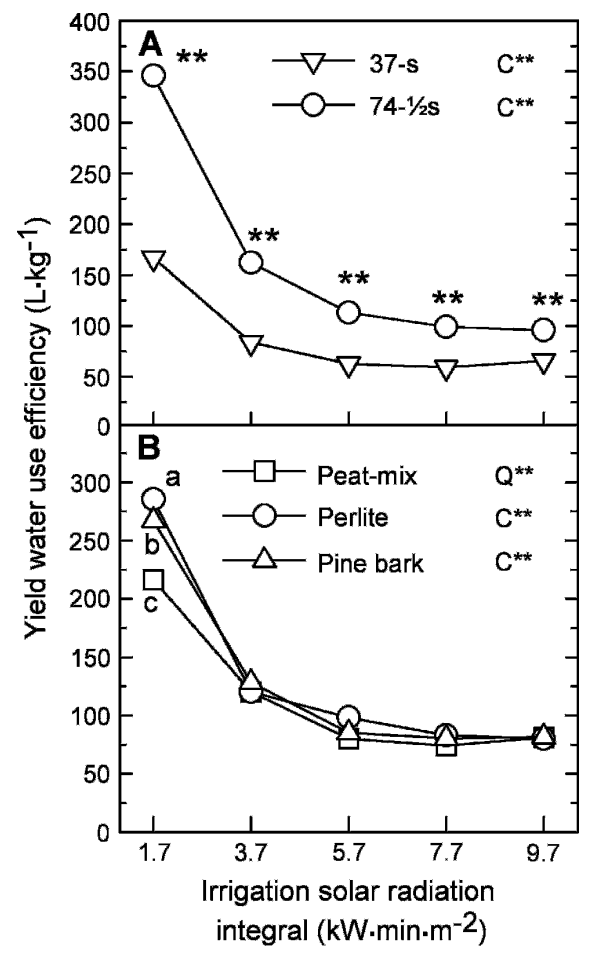

Fig. 10. (A, B) Bell pepper yield water use efficiency (liters of solution delivered per kilogram of marketable fruit) from plants in greenhouse Expt. 2 with irrigation events that delivered $37 \mathrm{~mL}$ of a solution with standard nutrient concentration levels (37-s) or $74 \mathrm{~mL}$ with half the concentration levels of nutrients $(74-1 / 2 \mathrm{~s} ; \mathbf{A})$, and grown in three soilless media, when irrigation events started at five levels of solar radiation integral $(\mathbf{B})$. **Significant $\mathrm{F}$ test $(P<0.01)$ for the corresponding level of radiation integral. C, Q, cubic and quadratic effect respectively for the corresponding volume per irrigation event or media. **Significant at $1 \%$ of probability. Means followed by the same letter within a radiation integral level are not significantly different with Duncan's multiple range test at the $5 \%$ level.

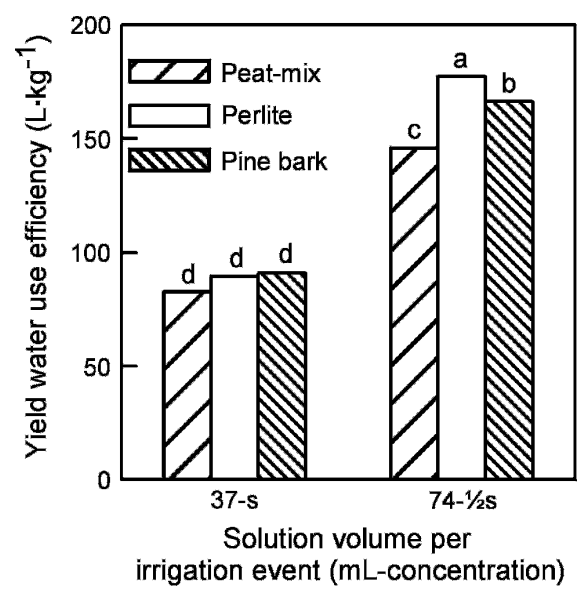

Fig. 11. Bell pepper yield water use efficiency (liters of solution delivered per kilogram of marketable fruit) in greenhouse Expt. 2. Fruit were harvested $5 \mathrm{Feb}$. to 4 May 2000 from plants grown in three soilless media and with irrigation events that delivered $37 \mathrm{~mL}$ of a solution with standard nutrient concentration levels (37-s) or $74 \mathrm{~mL}$ with half the concentration levels of nutrients $(74-1 / 2 \mathrm{~s})$. Bars with the same letter are not significantly different with Duncan's multiple range test at the $5 \%$ level.

\section{Literature Cited}

Adams, P. 1992. Crop nutrition in hydroponics. Acta Hort. 323:289-305.
Adams, P. 2002. Nutritional control in hydroponics, p. 211-261. In: D. Savvas and H. Passam (eds.). Hydroponic production of vegetables and ornamentals. Embryo, Athens, Greece.

Alarcón Vera, A.L. 1996. Fertirrigación del pimiento dulce en invernadero, p. 45-52. In: NamesnyA.V. (ed.). Pimientos. Compendios de Horticultura. 9th ed. Horticultura, Reus, Spain.

Allen, R.G., L.S. Pereira, D. Raes, and M. Smith. 1998. Crop evapotranspiration: Guidelines for computing crop water requirements. FAO irrigation and drainage paper 56. FAO, Food and Agriculture Organization of the United Nations, Rome, Italy.

Aloni, B., L. Karni, S. Moreshet, C. Yao, and C. Stanghellini. 1999. Cuticular cracking in bell pepper fruit: II. Effects of fruit water relations and fruit expansion. J. Hort. Sci. Biotechnol. $74: 1-5$.

Aloni, B., L. Karni, I. Rylski, Y. Cohen, Y. Lee, M. Fuchs, S. Moreshet, and C. Yao. 1998. Cuticular cracking in pepper fruit: I. Effects of night temperature and humidity. J. Hort. Sci. Biotechnol. 73:743-749.

Aloni, B., L. Karni, I. Rylski, and Z. Zaidman. 1994. The effect of nitrogen fertilization and shading on the incidence of "color spots" in sweet pepper (Capsicum annuum) fruit. J. Hort. Sci. 69:767-773.

An, C.G., Y.H. Hwang, H.S. Yoon, H.J. Hwang, C.W. Rho, G.W. Song, and B.R. Jeong. 2005. Effect of first irrigation time after sunrise on fruit quality and yield of sweet peppers (Capsicum annuum 'Jubilee' and 'Romeca') in rockwool culture. Korean J. Hort. Sci. Technol. $23: 146-152$
Burés, S. 1997. Sustratos. Agrotécnicas, Madrid, Spain.

Chartzoulakis, K. and N. Drosos. 1997. Water requirements of greenhouse grown pepper under drip irrigation. Acta Hort. 449:175-180.

Chrétien, S., A. Gosselin, and M. Dorais. 2000 High electrical conductivity and radiationbased water management improve fruit quality of greenhouse tomatoes grown in rockwool. HortScience 35:627-631.

Cochran, W.G. and G.M. Cox. 1957. Experimental designs. 2nd ed. Wiley, New York.

de Kreij, C., J. Janse, B.J. Van Goor, and J.D.J. Van Doesburg. 1992. The incidence of calcium oxalate crystals in fruit walls of tomato ( $\mathrm{LyCO}$ persicon esculentum Mill.) as affected by humidity, phosphate and calcium supply. J. Hort. Sci. 67:45-50.

de Kreij, C., L. van Veen-Schotanus, and P. Haghuis. 2005. Production and quality of tomato as affected by radiation-regulated electrical conductivity of drip solution. Acta Hort. 697:251-257.

Dorais, M., D.A. Demers, A.P. Papadopoulus, and A. Gosselin. 2001. Influence of electric conductivity management on greenhouse tomato yield and fruit quality. Agronomie 21: 367-383.

Dorais, M., D.A. Demers, A.P. Papadopoulus, and W.V. Ieperen. 2004. Greenhouse tomato cuticule cracking. Hort. Rev. (Amer. Soc. Hort. Sci.) 30:163-184.

Ehret, D.L., T. Helmer, and J.W. Hall. 1993 Cuticule cracking in tomato. J. Hort. Sci. 68: 195-201.

Ehret, D.L., A. Lau, S. Bittman, W. Lin, and T. Shelford. 2001. Automated monitoring of greenhouse crops. Agronomie 21:403-414.

Fernández, M.D., M. Gallardo, S. Bonachela, F. Orgaz, R.B. Thompson, and E. Fereres. 2005. Water use and production of a greenhouse pepper crop under optimum and limited water supply. J. Hort. Sci. Biotechnol. 80:87-96.

Fernández, M.D., F. Orgaz, E. Fereres, J.C. López, A. Céspedes, J. Pérez, S. Bonachela, and M. Gallardo. 2001. Programación del riego de cultivos hortícolas bajo invernadero en el sudeste español. Caja Rural de Almería y Málaga, Escobar Impresores, El Ejido, Spain.

Geraldson, C.M. 1957. Factors affecting calcium nutrition in celery, tomato and pepper. Soil Sci. Soc. Amer. Proc. 21:621-624.

Ho, L.C., R. Belda, M. Brown, J. Andrews, and P. Adams. 1993. Uptake and transport of calcium and the possible causes of blossomend rot in tomato. J. Expt. Bot. 44:509-518.

Hochmuth, G.J. 1991. Fertilizer management for greenhouse vegetables, p. 13-31. In: G.J. Hochmuth (ed.). Florida greenhouse vegetable production handbook. Vol. 3. University of Florida, Institute of Food and Agricultural Service, Gainesville, Fla., Circ. SP 48.

Jovicich, E. 2001. Hydroponic greenhouse pepper in Florida: Practices of plant trellising, population, transplant depth, soilless media, and irrigation. Department of Horticultural Sciences, University of Florida, Gainesville, Fla, MS thesis.

Jovicich, E., D.J. Cantliffe, S.A. Sargent, and L.S. Osborne. 2004a. Production of greenhousegrown peppers in Florida. Florida Cooperative Extension's Electronic Data Information Source (EDIS), Univ. of Florida, Gainesville, Fla. 20 Dec. 2006. <http://edis.ifas.ufl.edu/ HS228>.

Jovicich, E., D.J. Cantliffe, and P.J. Stoffella. 2004b. Fruit yield and quality of greenhousegrown bell pepper as influenced by density, 
container, and trellis system. HortTechnology 14:507-513.

Jovicich, E., J.J. VanSickle, D.J. Cantliffe, and P.J. Stoffella. 2005. Greenhouse-grown colored peppers: A profitable alternative to vegetable production in Florida? HortTechnology 15:355-369.

Kläring, H.P. 2001. Strategies to control water and nutrient supplies to greenhouse crops. A review. Agronomie 21:311-321.

Marcelis, L. and L.C. Ho. 1999. Blossom-end rot in relation to growth and calcium content in fruits of sweet pepper (Capsicum annuиm L.). J. Expt. Bot. 50:357-363.

Montgomery, D. 1997. Design and analysis of experiments. 4th ed. Wiley, New York.

Morris, L.G., F.E. Neale, and J.D. Postlethwaithe. 1957. The transpiration of glasshouse crops and its relationship to incoming solar radiation. J. Agr. Eng. Res. 2:111-122.

Nuez, F., R. Gil, and J. Costa. 1996. El cultivo de pimientos chiles y ajíes. Mundi-Prensa, Madrid, Spain.

Peet, M.M. 1992. Fruit cracking in tomato. HortTechnology 2:216-223.

Pérez Martínez, C.P. and J. Carreño Sánchez. 1996. Productividad del agua de riego en cultivos protegidos de pimiento en Almería, p. 642649. Proc. XIV Congreso Nacional de Riegos, 11-13 June 1996. Aguadulce, Almería, Spain.

Pokorny, F.A. 1987. Available water and root development within the micropores of pine bark particles. J. Environ. Hort. 5:89-92.
Portree, J. 1996. Greenhouse vegetable production guide for commercial growers. J. Portree (ed.). Extension Systems Branch, Ministry of Agriculture, Fisheries, and Food, B.C., Canada.

Raviv, M., R. Wallach, A. Silber, and A. Bar-Tal. 2002. Substrates and their analysis, p. 25-101. In: D. Savvas and H. Passam (eds.). Hydroponic production of vegetables and ornamentals. Embryo, Athens, Greece.

Rilsky, I., B. Aloni, L. Karni, and Z. Zaidman. 1994. Flowering, fruit set, fruit development and fruit quality under different environmental conditions in tomato and pepper crops. Acta Hort. 366:45-55.

SAS Institute. 1999. SAS/STAT user's guide v8. Vol. 1-3. SAS Institute, Cary, N.C.

Shaw, N. and D.J. Cantliffe. 2002. Brightly colored pepper cultivars for greenhouse production in Florida. Proc. Fla. State Hort. Soc. 115:236241.

Shelford, T.J., A.K. Lau, D.L. Ehret, and S.T. Chieng. 2004. Comparison of a new plantbased irrigation control method with lightbased irrigation control for greenhouse tomato production. Can. Biosyst. Eng. 46:1.1-1.6.

Shröder, F.G. and J.H. Lieth. 2002. Irrigation control in hydroponics, p. 263-298. In: D. Savvas and H. Passam (eds.). Hydroponic production of vegetables and ornamentals. Embryo, Athens, Greece.

Silber, A., M. Bruner, E. Kenig, G. Reshef, H. Zohar, I. Posalski, H. Yehezkel, S. Cohen, M. Dinar, and S. Assouline. 2005a. High fertiga- tion frequency and transient $\mathrm{NH}_{4}$ concentration: Effects on soilless-grown pepper. J. Hort. Sci. Biotechnol. 80:233-239.

Silber, A., M. Bruner, E. Kenig, G. Reshef, H. Zohar, I. Posalski, H. Yehezkel, D. Shmuel, S. Cohen, M. Dinar, E. Matan, I. Cohen, L. Karni, B. Aloni, and S. Assouline. 2005b. High fertigation frequency and phosphorous level: Effects on summer-grown bell pepper growth and blossom-end rot incidence. Plant Soil 270:135-146.

Silber, A., G. Xu, I. Levkovitch, S. Soriano, A. Bilu, and R. Wallach. 2003. High fertigation frequency: The effects on uptake of nutrients, water and plant growth. Plant Soil 253:467477.

Sonnenveld, C. 1979. Effects on salinity on the growth and mineral composition of sweet pepper and eggplant grown under glass. Acta Hort. 89:71-78.

Sonnenveld, C. 2002. Composition of nutrient solutions, p. 179-210. In: D. Savvas and H. Passam (eds.). Hydroponic production of vegetables and ornamentals. Embryo, Athens, Greece.

Wien, H.C. 1997. Peppers, p. 275. In: H.C. Wien (ed.). The physiology of vegetable crops. CAB International, University Press, Cambridge, UK.

Yao, C.R., S. Moreshet, B. Aloni, and L. Karni. 2000. The effects of climatic factors and water stress on the diurnal fluctuation in diameter of bell pepper fruit. J. Hort. Sci. Biotechnol. 75:6-11. 